\title{
3. RADIOLARIANS FROM THE CASCADIA MARGIN, LEG 146
}

\author{
J.-P. Caulet ${ }^{2}$
}

\begin{abstract}
Radiolarian abundances, recorded in core-catcher samples from all Leg 146 sites, are consistently rare. Detailed occurrences of 65 taxa were estimated in additional samples for Sites $889 / 890$ and 892 . Radiolarian events, calibrated with well-documented paleomagnetic reversals during Ocean Drilling Program Leg 145 (Morley and Nigrini, in press), offer a relatively good chronology for both locations. A continuous sequence of late Pliocene to Pleistocene age, with an average sedimentation rate of $9 \mathrm{~cm} / \mathrm{k}$.y., is recognized at Site 889 on the accretionary wedge off Vancouver Island. An intricate biostratigraphy, with several hiatuses and three stratigraphic reversals involving late Pliocene intervals underlying middle or late Miocene deposits, is proposed for Site 892 on the accretionary wedge under the Oregon continental slope. The occurrence of many species characteristic of upwelling environments records upwelling activity along the Oregon margin through most of the late Pliocene to early Pleistocene.
\end{abstract}

\section{INTRODUCTION}

Ocean Drilling Program (ODP) Leg 146 investigated tectonic dewatering in the accretionary wedge at the Cascadia continental margin. The sedimentary section resting on oceanic lithosphere is a thick accumulation (up to $3.5 \mathrm{~km}$ ) of turbidites and hemipelagic deposits. In this sedimentological environment, radiolarian fractions isolated from the sediment bulk are usually very small (less than $1 \%$ ), or often absent.

At all sites drilled during Leg 146 (Fig. 1), radiolarian debris is indeed very rare, but occurrence of some well-preserved stratigraphic

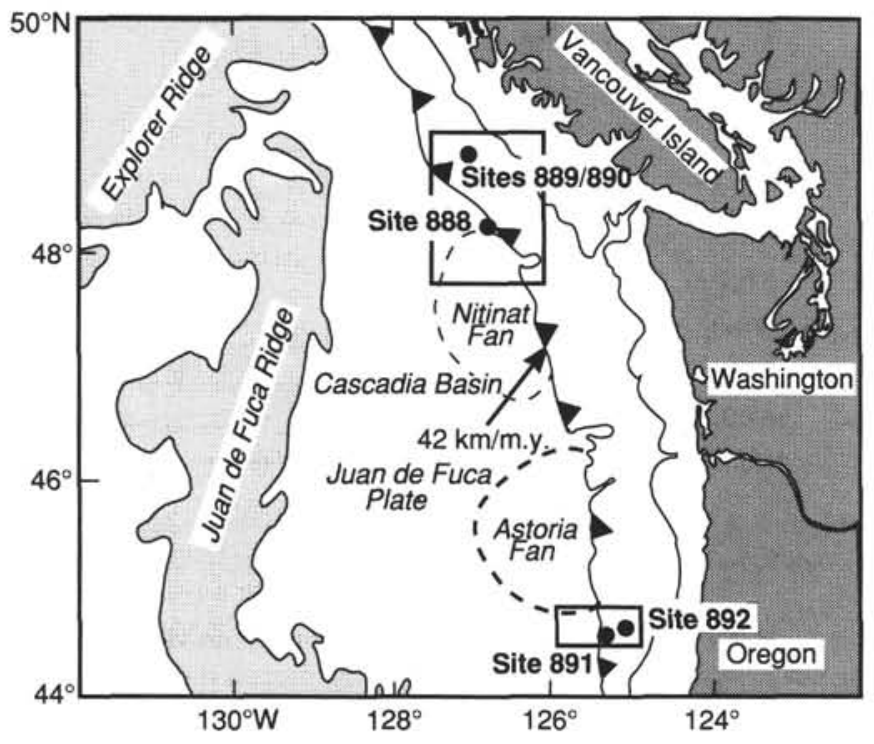

Figure 1. Location map of the Cascadia Margin, showing the convergent plate motion, major physiographic features, the position of the continental margin, and the position of drilling sites.

Carson, B., Westbrook, G.K., Musgrave, R.J., and Suess, E. (Eds.), 1995. Proc. ODP, Sci. Results, 146 (Pt. 1): College Station, TX (Ocean Drilling Program).

${ }^{2}$ Laboratoire de Géologie, Muséum National d'Histoire Naturelle, UA 723 du CNRS, 43 rue Buffon, 75005 Paris, France. markers in almost all holes allows a stratigraphic description of the different sedimentological sequences. Due to the scarcity of foraminiferal associations and a disturbed magnetostratigraphy, radiolarian biostratigraphy was very helpful during the cruise. After the cruise, shore-based studies of diatom assemblages have completed and confirmed the preliminary radiolarian biostratigraphy of the important Site 892 , providing a good stratigraphic framework for the tectonic and geochemical synthesis of this site (see this volume).

The main purpose of this paper is to provide, using additional samples, a more refined biostratigraphy for Sites 889 and 892 .

Radiolarian assemblages from Site 893 (Santa Barbara Basin) are not described here because the data they provide are mostly of paleoenvironmental importance and based on high-resolution counts of species assemblages that are beyond the scope of this report.

\section{PROCEDURES}

Sample preparation for microscopic examination during Leg 146 followed the standard techniques described by Sanfilippo et al. (1985). Samples were sieved first at $80 \mu \mathrm{m}$ to eliminate clay aggregates. A second mesh of $50 \mu \mathrm{m}$ was used for control. An additional cleaning of clay-rich sediments in a $5 \%$ ammonia solution was performed on samples prepared onshore.

For each sample examined, qualitative estimates of radiolarian abundance and preservation were made. Radiolarian assemblage abundance was assessed as follows:

$\mathrm{A}=$ abundant $(>500$ specimens on slide $)$

$\mathrm{C}=$ common $(100-500$ specimens on slide $)$

$\mathrm{F}=$ few $(50-100$ specimens on slide)

$\mathrm{R}=$ rare $(<50$ specimens on slide $)$

$\mathrm{VR}=$ very rare $(<10$ specimens on slide $)$

Preservation of the radiolarian assemblage was based on the following:

$\mathrm{G}(\mathrm{good})=$ radiolarians show no sign of dissolution with only minor fragmentation.

$\mathrm{M}($ moderate $)=$ radiolarians show evidence of moderate dissolution with obvious fragmentation.

$\mathrm{P}($ poor $)=$ radiolarians show signs of a high degree of dissolution with very few intact specimens. 


\section{Radiolarian Biostratigraphy}

During the cruise itself, a radiolarian zonation with six zones was used to date the Pliocene/Pleistocene sediments (see "Explanatory Notes" chapter in Westbrook, Carson, Musgrave, et al., 1994).

Mainly constructed from the work of Hays (1970), Kling (1971), Foreman (1975), Riedel and Sanfilippo (1970, 1971, 1978), and Morley (1985), radiolarian zones were defined as follows:

Botryostrobus aquilonaris Zone, Hays (1970): the base is defined by the last occurrence of Stylatractus universus. This zone extends to the top of Recent sediments.

Stylatractus universus Zone, Hays (1970): the base is defined by the last occurrence (LO) of Eucyrtidium matuyamai.

Eucyrtidium matuyamai Zone, Hays (1970); emend. Foreman (1975): the base is defined by the evolutionary transition from $E$. calvertense to $E$. matuyamai.

Lamprocyrtis heteroporos Zone, Hays (1970); emend. Foreman (1975): the base is defined by the LO of Stichocorys peregrina.

Sphaeropyle langii Zone, Foreman (1975): the base is defined by the FO of $S$. langii.

Stichocorys peregrina Zone, Riedel and Sanfilippo (1970); emend. Foreman (1975): the base is defined by the first evolutionary appearance of $S$. peregrina.

Using magnetostratigraphy, Morley and Nigrini (in press) have recently calculated good magnetic ages for many Neogene radiolarian events from the North Pacific. Radiolarian events occurring in Leg 146 sediments are now dated following the time chart established by Morley and Nigrini (in press) for the North Pacific radiolarian assemblages (Table 1).

As the last occurrence of $S$. peregrina (base of the $L$. heteroporos Zone) is now dated of $6.4 \mathrm{Ma}$ for the northeast Pacific, the Pliocene/ Pleistocene radiolarian zonation used in this paper is thus modified, and consists only of the four previous upper zones because the older $S$. langii and part of the $S$. peregrina Zones are now included in the $L$. heteroporos Zone (first occurrence of $S$. langii dated at $4.8 \mathrm{Ma}$ in the northeast Pacific).

Table 1. Radiolarian events in the North Pacific (after Morley and Nigrini, in press).

\begin{tabular}{llc}
\hline Event & \multicolumn{1}{c}{ Species } & $\begin{array}{c}\text { Age } \\
\text { (Ma) }\end{array}$ \\
\hline LO & Lychnocanoma nipponica sakai & 0.05 \\
LO & Stylacontarium acquilonium & 0.4 \\
LO & Stylatractus universus & 0.55 \\
FO & Lamprocyrtis nigriniae & $0.8-1.2$ \\
LO & Lamprocyrtis neoheteroporos & 0.9 \\
LO & Eucyrtidium matuyamai & 1.0 \\
LO & Lamprocyrtis heteroporos & 1.7 \\
LO & Sphaeropyle robusta & $1.5-1.7$ \\
FO & Eucyrtidium matuyamai & 2.0 \\
FO & Lamprocyrtis neoheteroporos & $2.6-2.8$ \\
FO & Cycladophora davisiana & 2.9 \\
FO & Sphaeropyle langii & 4.8 \\
LO & Dictyophimus splendens & 4.8 \\
LO & Theocorys redondoensis & 4.9 \\
LO & Stichocorys peregrina & 6.4 \\
FO & Lamprocyrtis heteroporos & 6.6 \\
LO & Stichocorys delmontensis & 6.8 \\
Transition & S. delmontensis-S. peregrina & 7.5 \\
FO & Stylacontarium acquilonium & 7.7 \\
LO & Cyrtocapsella japonica & 10.0 \\
FO & Dictyophimus splendens & 15.5 \\
FO & Theocorys redondoensis & 16.25 \\
\end{tabular}

\section{RADIOLARIAN BIOSTRATIGRAPHY OF LEG 146 SITES \\ Site 888 (Nitinat Fan)}

An apparently continuous sequence of upper Pleistocene sediments was cored at Site $888\left(48^{\circ} 10.00 \mathrm{~N}-126^{\circ} 39.79 \mathrm{E}\right)$. Radiolarians occurred in only a few intervals and in very low abundance.

Hole $888 \mathrm{~A}$, represented by a single core, recovered uppermost Quaternary sediments. An upper Pleistocene record $(\sim 0.7 \mathrm{Ma})$ was recovered from Hole 888B.

All core-catcher samples from Holes $888 \mathrm{~A}$ and $888 \mathrm{~B}$ were processed and examined for radiolarians. Rare and well-preserved radiolarians characteristic of the late Quaternary B. aquilonaris Zone ( $0.55 \mathrm{Ma}$ to present) were found in sediments near the top of the sequence from Hole 888A (Sample 146-888A-1H-CC at $9.5 \mathrm{mbsf}$ ) and in Samples 146-888B-1H-CC through - 18X-CC (5.4 to $162.5 \mathrm{mbsf}$ ) from Hole 888B. In this interval, four samples of coarse sand (Samples 146-888B-8H-CC, -9H-CC, $-12 \mathrm{H}-\mathrm{CC}$, and $-13 \mathrm{H}-\mathrm{CC} ; 72$ to 118 mbsf) are barren. Samples 146-888B-19X-CC through -36H-CC (172 to $319.8 \mathrm{mbsf}$ ) are barren. Very rare and well-preserved Pleistocene radiolarians were found in Samples 146-888B-37H-CC through $-41 \mathrm{X}-\mathrm{CC}$ (329.7 to $357.9 \mathrm{mbsf}$ ). No stratigraphic markers were recognized. All core catchers downhole are barren, with the exception of Sample 146-888B-54X-CC (471.5 mbsf), where rare Pleistocene radiolarians were observed.

All specimens are typical of the Arctic Pleistocene radiolarian assemblage. Rare species indicative of upwelling areas (Nigrini and Caulet, 1992) are present in Samples 146-888A-1H-CC (9.5 mbsf) and 146-888B-42X-CC (367.2 mbsf).

\section{Sites 889 and 890 \\ (Accretionary wedge off Vancouver Island)}

A sequence of upper Pliocene through upper Quaternary sediments was cored at Site $889\left(48^{\circ} 41.95 \mathrm{~N}-126^{\circ} 52.09 \mathrm{~W}\right)$, and an apparently continuous upper Quaternary sequence was cored at Site 890 $\left(48^{\circ} 39.75 \mathrm{~N}-126^{\circ} 52.89^{\prime} \mathrm{W}\right)$. Planktonic foraminifers, benthic foraminifers, and radiolarians are rare to abundant at these sites. Diatoms are common to abundant in radiolarian-bearing samples.

Occurrences of radiolarian species related to previously determined age data from Morley and Nigrini (in press) are recorded in Table 2 for Hole 889A.

\section{Hole $889 A$}

Well-preserved radiolarians are rare to abundant in Samples 146$889 \mathrm{~A}-1 \mathrm{H}-\mathrm{CC}$ (30.2 mbsf) to -37X-CC (275.4 mbsf). Samples 146$889 \mathrm{~A}-38 \mathrm{X}-\mathrm{CC}$ ( $284.2 \mathrm{mbsf})$ to $-44 \mathrm{X}-\mathrm{CC}$ ( $345.8 \mathrm{mbsf})$ are barren of radiolarians.

Samples 146-889A-1H-CC (30.2 mbsf) through 146-889A-8H-2, $96-101 \mathrm{~cm}(89.0 \mathrm{mbsf})$ contain a well-preserved assemblage dominated by Cycladophora davisiana, Lychnocanoma nipponica sakai, and Pterocorys clausus. This assemblage was previously correlated with the late Pleistocene B. aquilonaris Zone ( $0.55 \mathrm{Ma}$ to present) (Westbrook, Carson, Musgrave, et al., 1994). Radiolarian species indicative of upwelling environments, such as Lamprocyrtis nigriniae, Pterocanium auritum, and Pterocanium grandiporus (Nigrini and Caulet, 1992), were found in Samples 146-889A-2H-CC (39.9 mbsf), $-3 \mathrm{H}-\mathrm{CC}$ ( $50.0 \mathrm{mbsf})$, and $-7 \mathrm{H}-\mathrm{CC}$ ( $86.4 \mathrm{mbsf})$.

This interval was previously related to the $B$. aquilonaris Zone because the LO of $S$. universus was reported at 89.0 mbsf. Additional radiolarian events published by Morley and Nigrini (in press) help to define possible absolute ages for some parts of this interval: 
Table 2. Range chart of radiolarian species at Hole 889A.

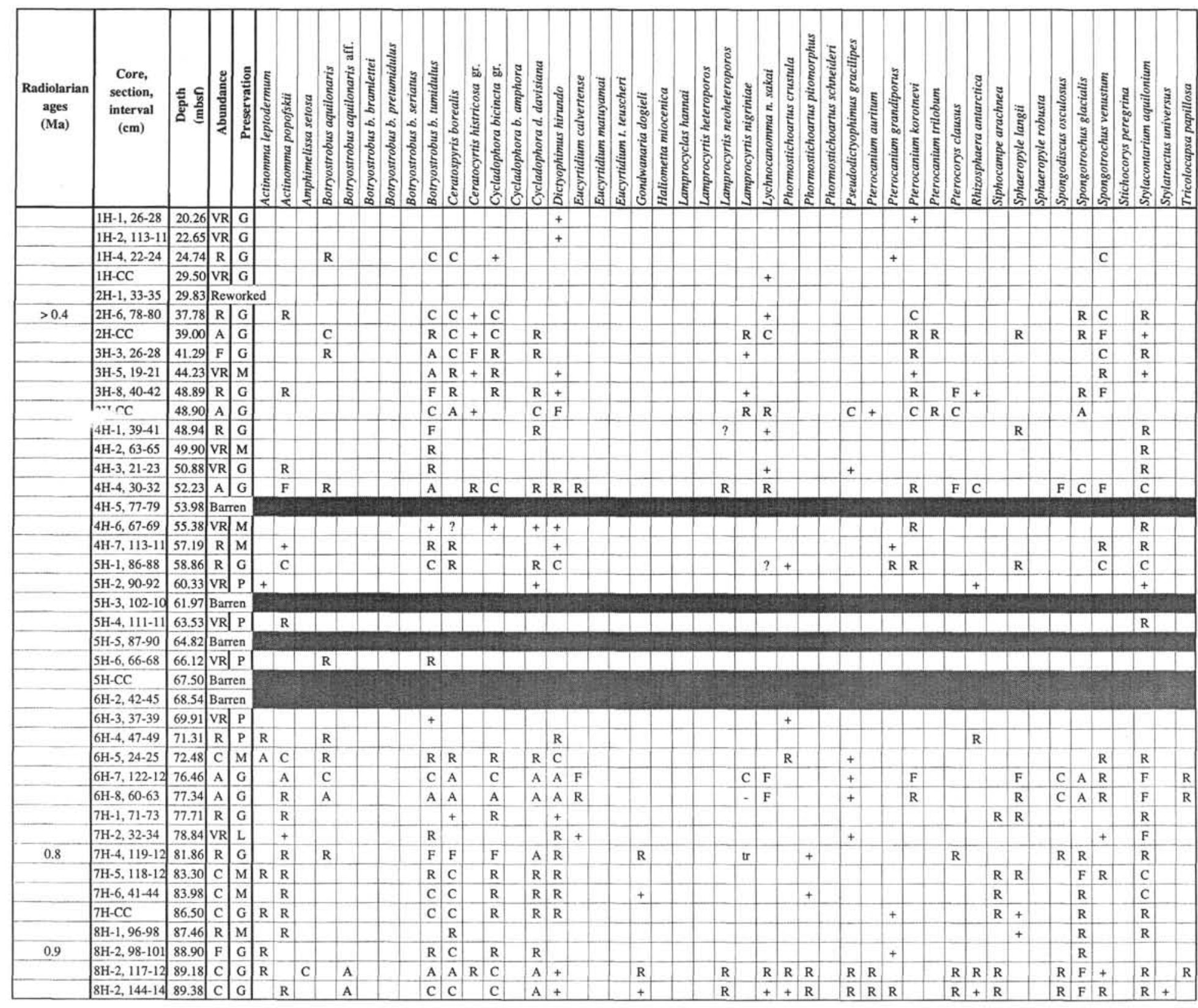

Notes: see text for explanation of entries. Radiolarian ages were estimated using radiolarian events calibrated by Morley and Nigrini (in press). 
Table 2 (continued).

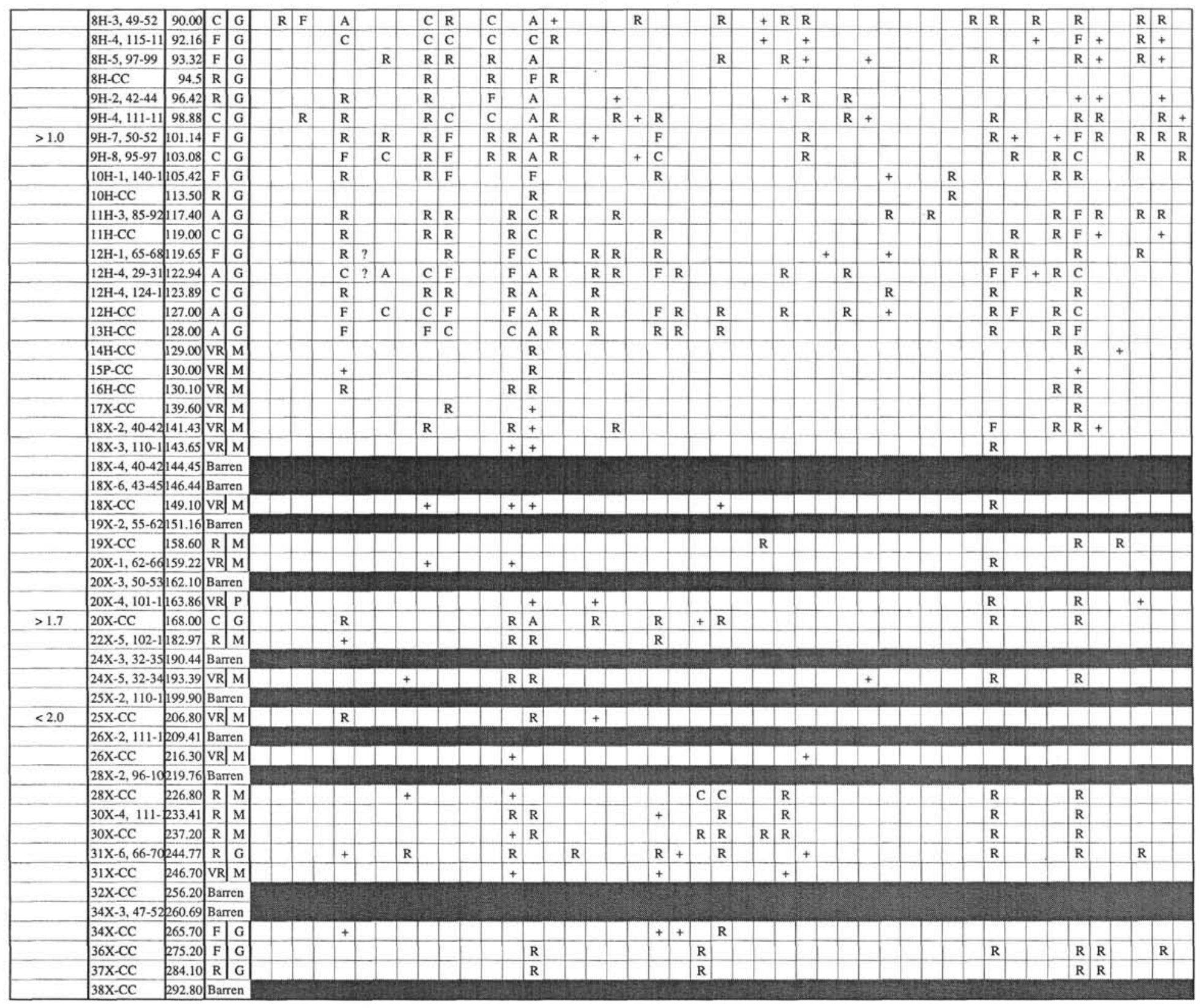


a. the occurrence of a specimen of $L$. n. sakai in Sample 146$889 \mathrm{~A}-1 \mathrm{H}-\mathrm{CC}$ (30.2 mbsf) gives an age older than $0.05 \mathrm{Ma}$ to this sample;

b. the LO of Stylacontarium acquilonium in Sample 146$889 \mathrm{~A}-2 \mathrm{H}-6,78-80 \mathrm{~cm}$ (37.78 mbsf) gives an age older than $0.4 \mathrm{Ma}$ to this sample.

As the LO of S. universus (Table 1) is older than the LO of S. acquilonium (Morley and Nigrini, in press), we can consider the base of the $B$. aquilonaris Zone to be just below $37.78 \mathrm{mbsf}$. The question then becomes why no representatives of $S$. universus are present in most Pleistocene sediments from Hole 889A, particularly in wellpreserved and diverse assemblages. Observations on shallow sites studied in the Antarctic (Caulet, 1991) and on the Peru Margin (De Wever et al., 1990) would indicate that debris of S. universus may be rare to absent at shallow depths, but no conclusive data are yet published.

The LO of E. matuyamai dates Sample 146-889A-9H-7, 50-52 $\mathrm{cm}(101.14 \mathrm{mbsf})$ at $>1.0 \mathrm{Ma}$, in the late Pliocene/early Pleistocene E. matuyamai Zone (2.0 to $1.0 \mathrm{Ma}$ ). The interval between the LO of $S$. acquilonium and the LO of E. matuyamai can be considered as representing the $S$. universus Zone, and the hiatus previously deduced from the absence of $S$. universus in sediments above 89.38 mbsf can be now rejected. The FO of $L$. nigriniae (transitional forms) in Sample 146-889A-7H-4, 119-121 cm (81.86 mbsf) and the LO of L. neoheteroporos in Sample 146-889A-8H-2, 117-120 cm (89.18 mbsf) give an age of 0.8 to $0.9 \mathrm{Ma}$ to this interval.

The first occurrence of E. matuyamai (at the base of the E. matuyamai Zone) is located between Sample 146-889A-25X-CC (200.7 mbsf) and Sample 146-889A-26X-CC (215.4 mbsf), giving an age of nearly $2.0 \mathrm{Ma}$ to the sediments drilled at $206.80 \mathrm{mbsf}$. The LO of $L$. heteroporos (1.7 Ma) is recorded in Sample 146-889A-20X-CC (168.00 mbsf). Reworked specimens of early Pliocene species, such as $C$. davisiana (ancestral form), $S$. peregrina, and Sphaeropyle robusta, occur in many samples within this interval, suggesting erosional and transportation processes during the early Pleistocene. Radiolarian species indicative of upwelling environments, such as $P$. grandiporus, L. nigriniae, and Phormostichoartus crustula, were found in Samples 146-889A-10H-1, 140-144 cm (105.4 mbsf), 146$889 \mathrm{~A}-11 \mathrm{H}-3,88-92 \mathrm{~cm}$ (117.4 mbsf), and 146-889A-12H-4, 124 $128 \mathrm{~cm}$ (123.9 mbsf).

Rare to few radiolarians assign the interval between Samples 146889A-26X-CC (215.4 mbsf) and -37X-CC (284.10 mbsf) to the late Pliocene $L$. heteroporos Zone (6.4 to $2.0 \mathrm{Ma}$ ). The occurrence of rare representatives of $C$. davisiana assigns an age younger than $2.9 \mathrm{Ma}$ to Sample 146-889A-37X-CC (284.10 mbsf). Rare representatives of the upwelling radiolarian marker $P$. crustula suggest an upwelling influence in sediments of Samples 146-889A-30X-CC and -31X-CC between 235 and 247 mbsf. No reworked fauna was observed.

Samples 146-889A-39X-CC through -44X-CC (294.0 to 338.7 mbsf) are barren of radiolarians.

\section{Hole $889 B$}

Sample 146-889B-3R-CC (218.2 mbsf) is barren of radiolarians. Rare to few representatives of the North Pacific radiolarian assemblage were found in Samples 146-889B-4R-CC and -5R-CC (228.2 and $235.2 \mathrm{mbsf}$ ). The occurrence of $L$. heteroporos and the absence of E. matuyamai suggest a late Pliocene age for this interval. Samples 146-889B-6R-CC through -8R-CC (248.2 to $269.5 \mathrm{mbsf}$ ) are barren of radiolarians. Rare radiolarians of late Pliocene age were observed in Samples 146-889B-9R-CC and -10R-CC (273.9 and $284.4 \mathrm{mbsf}$ ). Farther downhole in Hole 889B, all core-catcher samples contain rare radiolarians. No stratigraphic markers were recognized. Radiolarian species characteristic of upwelling environments, such as Acrosphaera murrayana and $P$. crustula, were found in Sample 146889B-14R-CC (317.8 mbsf).

\section{Hole 889D}

Rare to few radiolarians were found in Samples 146-889D-1HCC through $-3 \mathrm{X}-\mathrm{CC}$ ( 89.7 to $141.2 \mathrm{mbsf}$ ). No stratigraphic markers were recognized. Sample 146-889D-4N-CC (151.9 mbsf) is barren of radiolarians.

\section{Holes $890 \mathrm{~A}$ and $890 \mathrm{~B}$}

All core-catcher samples from Site 890 were examined for radiolarians. Sample 146-890A-1H-CC (3.7 mbsf) contains a diverse radiolarian assemblage assigned to the Pleistocene $B$. aquilonaris Zone (0.55 Ma to present).

Few radiolarians, representative of the late Pleistocene $B$. aquilonaris Zone, were found in Sample 146-890B-1H-CC (7.3 mbsf). Samples $146-890 \mathrm{~B}-2 \mathrm{H}-\mathrm{CC}$ to $-5 \mathrm{H}-\mathrm{CC}$ (17.5 to $48.8 \mathrm{mbsf}$ ) are barren of radiolarians.

\section{Site 891 (Oregon continental margin)}

The sediments recovered at Site $891\left(44^{\circ} 38.64 \mathrm{~N}-125^{\circ} 19.55^{\prime} \mathrm{W}\right)$ afford poor biostratigraphic control throughout most of the sequence. Factors contributing to the uncertainty in age determinations include: (1) the occurrence of several intervals barren of microfossils, (2) poor sedimentary recovery, and (3) the absence of zonal markers.

All core-catcher samples from Holes $891 \mathrm{~A}$ and $891 \mathrm{~B}$ were processed and examined for radiolarians. Rare to common and well-preserved radiolarians characteristic of the late Quaternary were found in sediments near the top of the sequence from Hole 891A (Samples 146-891 A-1H-CC to -3H-CC, 0 to $9.5 \mathrm{mbsf}$ ). Radiolarian species indicative of upwelling environments ( $L$. nigriniae and $P$. crustula were found in Sample 146-891A-2H-CC, at $7.3 \mathrm{mbsf}$.

Only rare radiolarian debris was found in the upper part of Hole 891B (Samples 146-891A-1X-CC to -10X-CC, 0 to $83.6 \mathrm{mbsf}$ ), except in Sample 146-891B-7X-CC (56.2 mbsf) where two stratigraphic and/or upwelling markers ( $L$. nigriniae and $P$. auritum $)$ indicate a Pleistocene age. Samples 146-891B-10X-CC to -31 X-CC (83.6 to $244.5 \mathrm{mbsf}$ ) are barren of radiolarians.

Radiolarians were very rare to rare in Samples 146-891B-32X$\mathrm{CC}$ to $-40 \mathrm{X}-\mathrm{CC}$ ( 252.4 to $306.1 \mathrm{mbsf}$ ). No stratigraphic or paleoenvironmental markers were observed. The species composition of these sparse assemblages could be indicative of a Pleistocene age.

Samples $146-891 \mathrm{~B}-42 \mathrm{X}-\mathrm{CC}$ to $-52 \mathrm{X}-\mathrm{CC}$ (323.1 to $411.6 \mathrm{mbsf}$ ) are barren of radiolarians. Radiolarians occur rarely in the interval between Samples 146-891B-55X-CC and -57X-CC (440.1 to 455.3 mbsf). The occurrence of C. davisiana in Sample 146-891B-57X-CC (455.3 mbsf) indicates a Pliocene-Pleistocene age. Sample 146891B-58X-CC (465.9 mbsf) is barren of radiolarians.

\section{Site 892 (Accretionary wedge under the Oregon continental slope)}

A discontinuous sequence of upper Neogene sediments was cored at Site $892\left(44^{\circ} 40.45^{\prime} \mathrm{N}-125^{\circ} 7.13^{\prime} \mathrm{W}\right)$. Poorly to moderately preserved planktonic foraminifers and poorly to well-preserved benthic foraminifers and radiolarians are rare to common at this site. Diatoms are common to abundant in radiolarian-bearing samples.

Occurrences of radiolarian species are recorded in Table 3 for Hole 892A, and in Table 4 for Holes 892D and 892E. Radiolarian events and inferred radiolarian ages in Hole 892A are summarized in Table 5 .

\section{Hole $892 A$}

Sample 146-892A-1X-1, 128-130 cm (1.29 mbsf), contains a well-preserved assemblage. The co-occurrence of $L$. nigriniae and well-preserved specimens of $L$. neoheteroporos, and the absence of 
Table 3. Range chart of radiolarian species at Hole 892A.

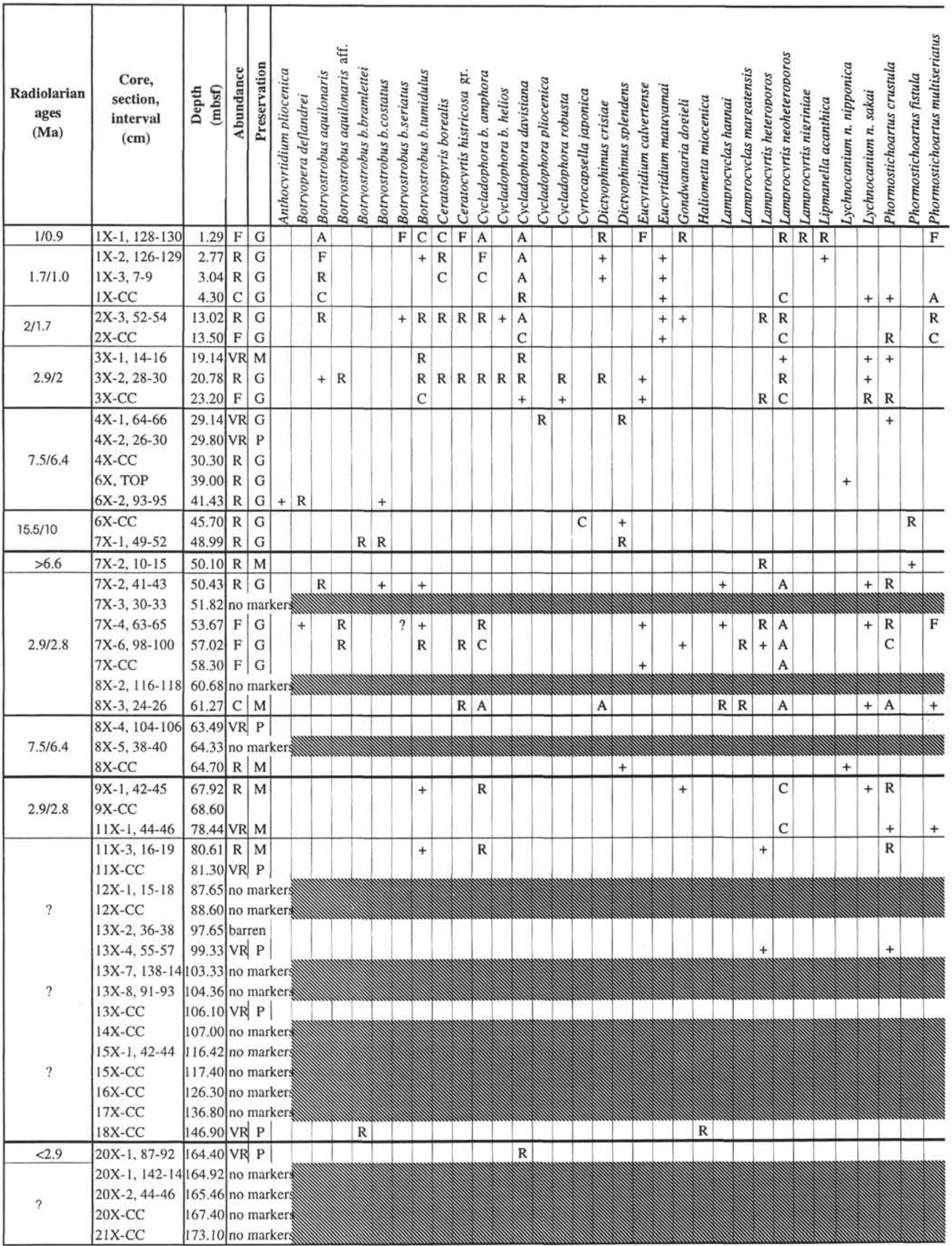

Notes: see text for explanation of entries. Radiolarian ages were estimated using radiolarian events calibrated by Morley and Nigrini (in press). 


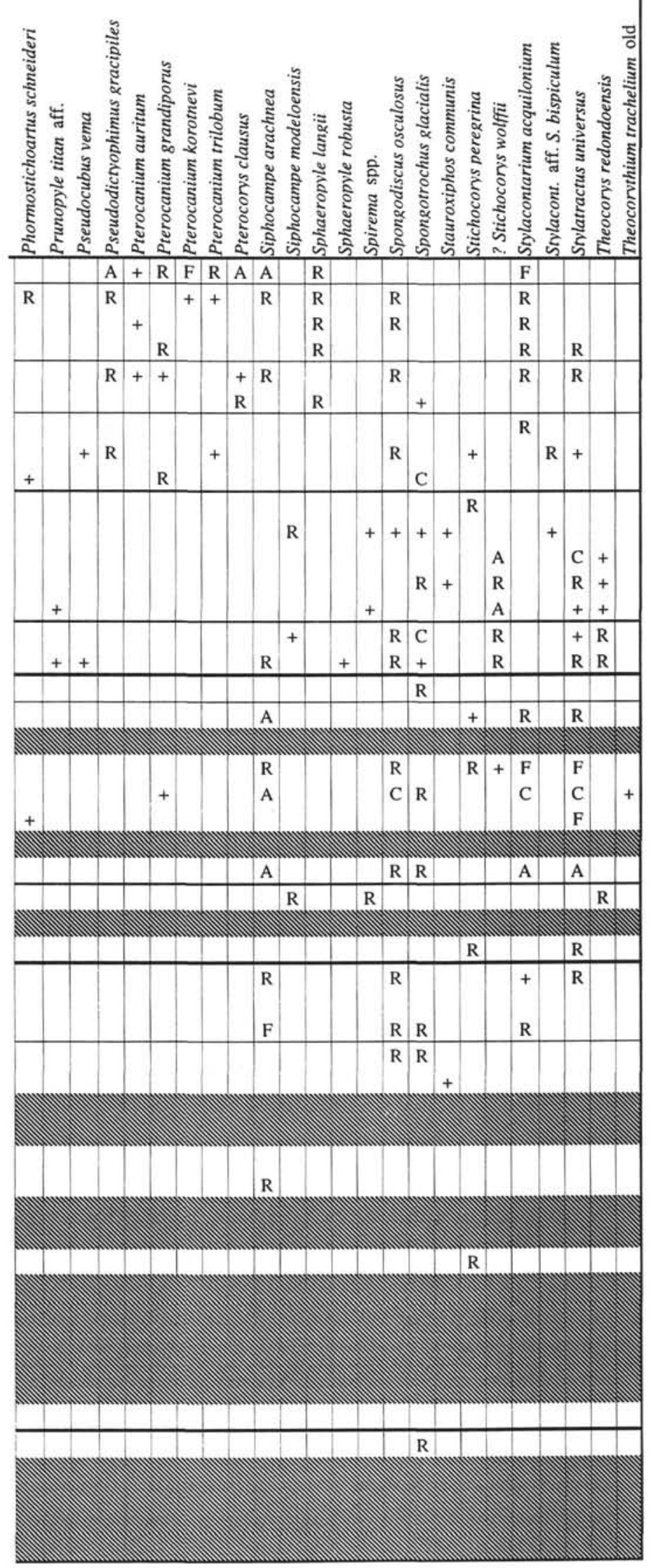


Table 4. Range chart of radiolarian species at Hole 892D and 892E.

\begin{tabular}{|c|c|c|c|c|c|c|c|c|c|c|c|c|c|c|c|c|c|c|c|c|c|c|c|c|c|c|c|c|c|c|}
\hline $\begin{array}{c}\text { Radiolarian } \\
\text { ages } \\
\text { (Ma) }\end{array}$ & $\begin{array}{l}\text { Core, section, } \\
\text { interval }(\mathrm{cm})\end{array}$ & 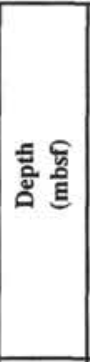 & 㝕 & $\mid$ & 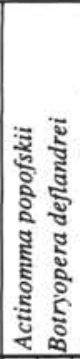 & 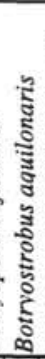 & & & 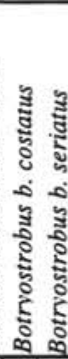 & 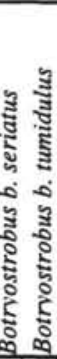 & & 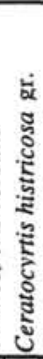 & 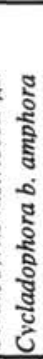 & & & 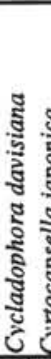 & 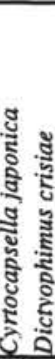 & 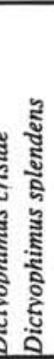 & 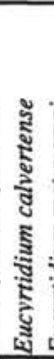 & 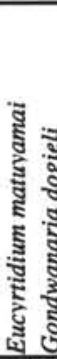 & 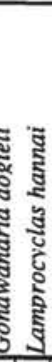 & 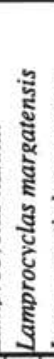 & 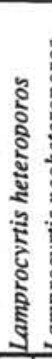 & 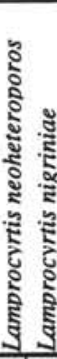 & 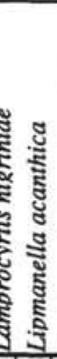 & 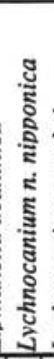 & है & 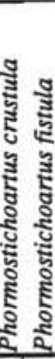 & 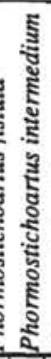 & 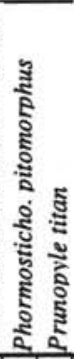 \\
\hline $1.2-0.9$ & $\begin{array}{l}\text { 892D-1X, CC } \\
892 \mathrm{D}-2 \mathrm{X}-1,6-9 \\
892 \mathrm{D}-2 \mathrm{X}-2,6-8\end{array}$ & \begin{tabular}{r|}
8.50 \\
8.56 \\
10.06 \\
\end{tabular} & \begin{tabular}{l|} 
A \\
C \\
R
\end{tabular} & \begin{tabular}{l|}
$G$ \\
$G$ \\
$G$
\end{tabular} & & $\begin{array}{l}\mathrm{R} \\
\mathrm{R} \\
\end{array}$ & + & & & $\mathrm{R}$ & A & $\begin{array}{l}\mathrm{R} \\
\mathrm{R} \\
\end{array}$ & $\begin{array}{l}\mathrm{A} \\
\mathrm{C}\end{array}$ & & & \begin{tabular}{l|l|}
$A$ & \\
$A$ & \\
$C$ & \\
\end{tabular} & $\begin{array}{l}\mathrm{R} \\
\mathrm{R} \\
\end{array}$ & & \begin{tabular}{|l|}
$R$ \\
$R$
\end{tabular} & + & & & & $\begin{array}{r}+ \\
+ \\
+\end{array}$ & & & & & & \\
\hline $2-1$ & $\begin{array}{l}\text { 892D-2X, CC } \\
\text { 892D-3X-1, 5-7 } \\
\text { 892D-3X,CC }\end{array}$ & $\begin{array}{l}18.00 \\
18.05 \\
27.50 \\
\end{array}$ & $\begin{array}{l}R \\
R \\
R\end{array}$ & \begin{tabular}{|l|} 
G \\
G \\
G \\
\end{tabular} & & & C & & & $R$ & & $\mathbf{R}$ & R & & & $\begin{array}{l}\mathrm{R} \\
\mathrm{R} \\
\mathrm{R}\end{array}$ & & & & & $\begin{array}{l}+ \\
+\end{array}$ & & & \begin{tabular}{l|l}
$R$ & \\
$R$ & \\
$R$ & \\
\end{tabular} & & & & & & R \\
\hline $2.9-2$ & $\begin{array}{l}\text { 892D-4X-1, 29-31 } \\
\text { 892D-4X-3, 28-30 } \\
\text { 892D-4X, CC } \\
892 \mathrm{D}-5 \mathrm{X}-1,52-54\end{array}$ & $\begin{array}{l}27.79 \\
30.30 \\
37.00 \\
37.52 \\
\end{array}$ & $\begin{array}{l}R \\
R \\
R \\
R\end{array}$ & $\begin{array}{l}\text { G } \\
\text { G } \\
\text { G } \\
\text { G }\end{array}$ & & & $\mathrm{R}$ & $\mathrm{R}$ & & $\mathrm{R}$ & $\begin{array}{l}\mathrm{C} \\
\mathrm{R}\end{array}$ & $\begin{array}{l}\mathrm{R} \\
\mathrm{R} \\
\end{array}$ & $\begin{array}{l}\mathrm{C} \\
\mathrm{R} \\
\mathrm{R}\end{array}$ & + & & $\begin{array}{l}\mathrm{C} \\
\mathrm{Ro} \\
\mathrm{Ro} \\
\mathrm{Ro}\end{array}$ & R & & $\begin{array}{l}+ \\
+ \\
+\end{array}$ & & $\begin{array}{l}+ \\
+\end{array}$ & & $+\frac{B}{B}$ & $\begin{array}{l}\mathrm{C} \\
\mathrm{R}\end{array}$ & & & $\begin{array}{l}+ \\
\mathrm{R} \\
\mathrm{R} \\
+ \\
+\end{array}$ & & & R \\
\hline $15.5-10$ & $\begin{array}{l}892 \mathrm{D}-5 \mathrm{X}-2,95-97 \\
892 \mathrm{D}-5 \mathrm{X}-3,125-127 \\
892 \mathrm{D}-5 \mathrm{X}, \mathrm{CC} \\
892 \mathrm{D}-6 \mathrm{X}-1,83-86 \\
892 \mathrm{D}-6 \mathrm{X}-3,91-94 \\
892 \mathrm{D}-6 \mathrm{X}-4,74-77 \\
892 \mathrm{D}-6 \mathrm{X}-5,67-70 \\
892 \mathrm{D}-6 \mathrm{X}, \mathrm{CC} \\
892 \mathrm{D}-7 \mathrm{X}-1,73-76 \\
892 \mathrm{D}-7 \mathrm{X}-2,25-28 \\
892 \mathrm{D}-7 \mathrm{X}-3,74-77 \\
892 \mathrm{D}-7 \mathrm{X}-4,113-116 \\
892 \mathrm{D}-7 \mathrm{X}-5,32-34\end{array}$ & \begin{tabular}{l|}
39.45 \\
41.25 \\
46.50 \\
47.33 \\
50.16 \\
51.49 \\
52.92 \\
54.00 \\
54.73 \\
55.75 \\
57.50 \\
59.39 \\
60.08 \\
\end{tabular} & \begin{tabular}{|c|}
$R$ \\
$R$ \\
$R$ \\
$R$ \\
$R$ \\
$V R$ \\
$R$ \\
$R$ \\
$R$ \\
$V R$ \\
$R$ \\
$V R$ \\
$V R$
\end{tabular} & \begin{tabular}{|l|} 
G \\
G \\
G \\
G \\
G \\
G \\
G \\
G \\
G \\
G \\
G \\
G \\
G
\end{tabular} & $\begin{array}{l}\mathrm{C} \\
\mathrm{C} \\
\mathrm{R} \\
\mathrm{R}\end{array}$ & & & $?$ & + & & & & & & & r & $\begin{array}{l}\text { C } \\
\text { R }\end{array}$ & + & & & & & & & & $\begin{array}{l}\mathrm{R} \\
\mathrm{R} \\
\mathrm{R}\end{array}$ & $R$ & Ro & & $\begin{array}{l}\mathrm{R} \\
\mathrm{R}\end{array}$ \\
\hline reworked & $\begin{array}{l}892 \mathrm{D}-7 \mathrm{X}-6,21-23 \\
892 \mathrm{D}-7 \mathrm{X}, \mathrm{CC} \\
892 \mathrm{D}-8 \mathrm{X}-1,43-45 \\
892 \mathrm{D}-8 \mathrm{X}-2,57-60 \\
892 \mathrm{D}-8 \mathrm{X}-2,117-119 \\
892 \mathrm{D}-8 \mathrm{X}-3,65-67 \\
892 \mathrm{D}-8 \mathrm{X}, \mathrm{CC} \\
892 \mathrm{D}-9 \mathrm{X}, \mathrm{CC}\end{array}$ & $\begin{array}{l}61.24 \\
61.70 \\
62.13 \\
63.57 \\
64.17 \\
65.15 \\
69.30 \\
77.60\end{array}$ & \begin{tabular}{|c|}
$C$ \\
$R$ \\
$R$ \\
$V R$ \\
$V R$ \\
$V R$ \\
$V R$ \\
barre \\
$V R$
\end{tabular} & \begin{tabular}{|c|} 
G \\
M \\
G \\
G \\
G \\
G \\
ren \\
M
\end{tabular} & & & $R$ & + & + & $\begin{array}{l}\mathrm{R} \\
\mathrm{R}\end{array}$ & & & $R$ & & $R$ & & & & + & & & $\begin{array}{l}+ \\
+ \\
+\end{array}$ & 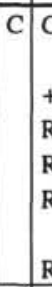 & $\begin{array}{l}+ \\
R \\
R \\
R\end{array}$ & & $R$ & R & \begin{tabular}{l|l}
$R$ & $R$ \\
$R$
\end{tabular} & $R$ & \\
\hline & $\begin{array}{l}\text { 892D-10X-3, 45-48 } \\
892 \mathrm{D}-10 \mathrm{X}-6,26-27 \\
892 \mathrm{D}-10 \mathrm{X}, \mathrm{CC} \\
892 \mathrm{D}-11 \mathrm{X}-1,20-22\end{array}$ & $\begin{array}{l}102.70 \\
107.31 \\
109.50 \\
109.70\end{array}$ & $\begin{array}{l}\text { barre } \\
\text { barre } \\
\text { barre } \\
\text { barre }\end{array}$ & $\begin{array}{l}\text { ren } \\
\text { ren } \\
\text { ren } \\
\text { ren }\end{array}$ & & & & & & & & & & & & & & & & & & & & & & & & & & \\
\hline$<2.9-2.8$ & $\begin{array}{l}\text { 892D-11X-2, 46-48 } \\
\text { 892D-11X, CC }\end{array}$ & $\begin{array}{l}111.46 \\
119.00\end{array}$ & \begin{tabular}{|l|}
$\mathrm{VR}$ \\
$\mathrm{VR}$
\end{tabular} & & & & & & & + & & & & & +1 & $\begin{array}{l}\mathrm{R} \\
\mathrm{R}\end{array}$ & & & & & + & & \begin{tabular}{l|l}
$\mathrm{R}$ & $\mathrm{R}$ \\
\end{tabular} & $\mathbf{R}$ & & & & & & \\
\hline ? & $\begin{array}{l}892 \mathrm{D}-12 \mathrm{X}-2,91-93 \\
892 \mathrm{D}-12 \mathrm{X}-3,81-83 \\
892 \mathrm{D}-12 \mathrm{X}, \mathrm{CC} \\
892 \mathrm{D}-13 \mathrm{X}, \mathrm{CC} \\
892 \mathrm{D}-14 \mathrm{X}, \mathrm{CC} \\
892 \mathrm{D}-15 \mathrm{X}-1,80-83\end{array}$ & $\begin{array}{l}121.41 \\
122.81 \\
128.50 \\
138.00 \\
147.50 \\
148.30\end{array}$ & $\begin{array}{l}\text { no m } \\
\text { VRl } \\
\text { no m } \\
\text { no m } \\
\text { no m } \\
\text { no m }\end{array}$ & $\begin{array}{l}\text { marke } \\
|\mathrm{P}| \\
\text { marke } \\
\text { marke } \\
\text { marke } \\
\text { marke }\end{array}$ & cers & & & & & + & & & & & 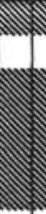 & & & & & & & & + & + & & & & & & \\
\hline & $\begin{array}{l}892 \mathrm{D}-15 \mathrm{X}-2,37-39 \\
892 \mathrm{D}-15 \mathrm{X}-3,77-79 \\
892 \mathrm{D}-16 \mathrm{X}-4,106-108 \\
892 \mathrm{D}-16 \mathrm{X}-5,53-55\end{array}$ & $\begin{array}{l}149.37 \\
121.27 \\
162.09 \\
163.06\end{array}$ & $\begin{array}{l}\text { VRl } \\
\text { no m } \\
\text { no m } \\
\text { no } m\end{array}$ & $\begin{array}{l}|\mathrm{P}| \\
\text { marke } \\
\text { marke } \\
\text { marke }\end{array}$ & cers & & & & & $R$ & & & & & + & & & & & & & & t & + & & & $R$ & $\mathbf{R}$ & & \\
\hline
\end{tabular}

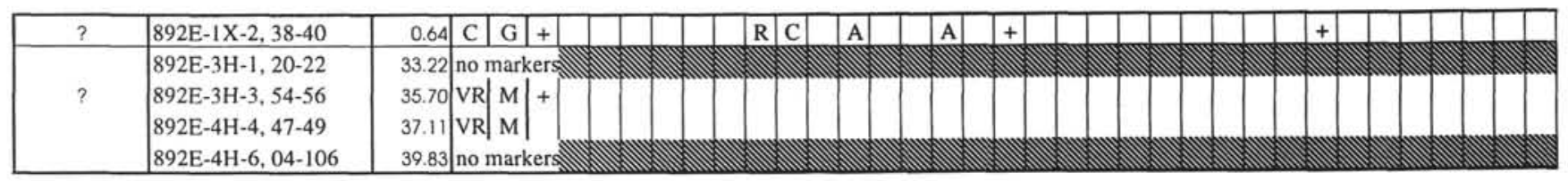


Table 4 (continued).
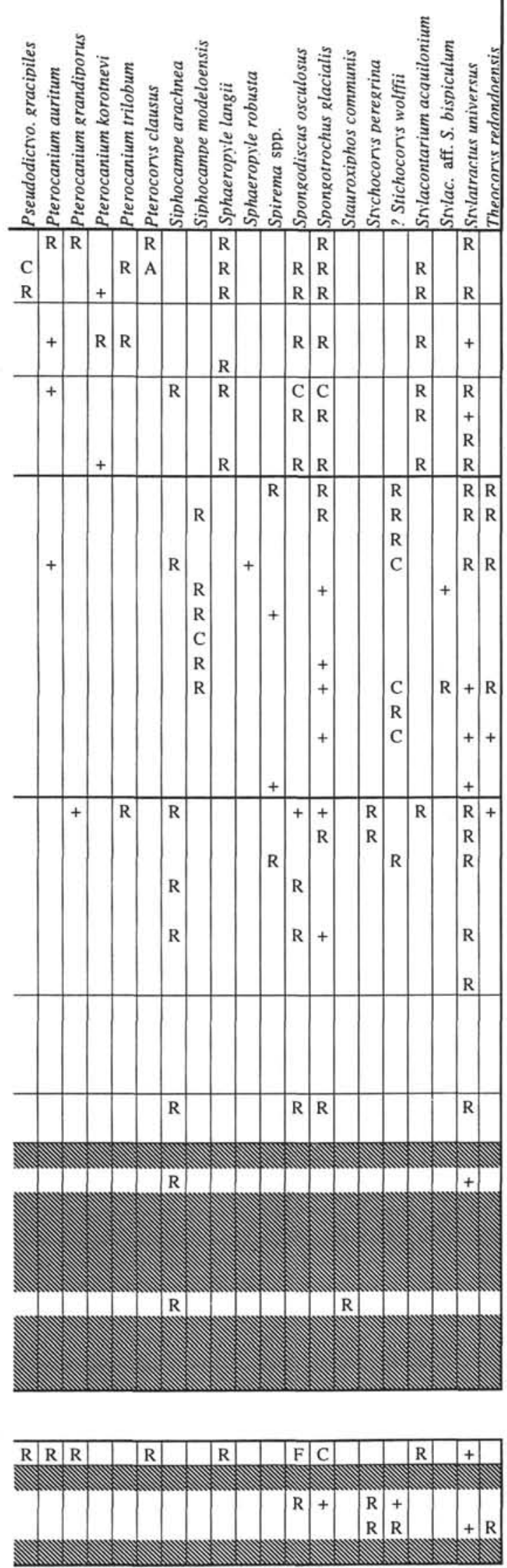
Table 5. Radiolarian event chart for Hole 892A.

\begin{tabular}{|c|c|c|c|}
\hline $\begin{array}{l}\text { Core, section, } \\
\text { interval }(\mathrm{cm})\end{array}$ & Depth (mbsf) & Age (Ma) & Events \\
\hline $892 \mathrm{~A}-1 \mathrm{X}-1,128-130$ & 1.29 & $1 / 0.9$ & Co-occurrence of $L$ nigriniae and $L$ neoheteroporos \\
\hline $1 X-2,126-129$, to & 2.77 & \multirow{2}{*}{$1.7 / 1$} & Occurrences of E. matuyamai. P. pitomorphus, and L. neoheteroporos; \\
\hline $1 \mathrm{X}-\mathrm{CC}$ & 4.30 & & absence of $L$. heteroporos \\
\hline $2 X-3,52-54$, to & 13.02 & \multirow[t]{2}{*}{$2 / 1.7$} & \multirow[t]{2}{*}{ Occurrences of $L$. heteroporos, $L$ neoheteroporos, and $E$. matuyamai } \\
\hline $2 \mathrm{X}-\mathrm{CC}$ & 13.50 & & \\
\hline $3 \mathrm{X}-1,14-16$, to & 19.14 & \multirow{2}{*}{$2.9 / 2$} & Occurrences of $C$ davisiana, $L$. neoheteroporos; absence of $E$. matuyamai \\
\hline $3 \mathrm{X}-\mathrm{CC}$ & 23.20 & & Occurrences of $L$. neoheteroporos and $L$. heteroporos: no $C$. davisiana \\
\hline $4 X-1,64-66$, to & 29.14 & \multirow{2}{*}{$7.5 / 6.4$} & Occurrences of $S$, peregrina and $D$. splendens \\
\hline $6 \mathrm{X}-2,93-95$ & 41.43 & & Occurrences of $T$. redondoensis and $A$. pliocenica \\
\hline $6 \mathrm{X}-\mathrm{CC}$, to & 45.70 & \multirow{2}{*}{$15.5 / 10$} & Occurrences of $C$. japonica, D. splendens, $P$. vema, T. redondoensis, \\
\hline $7 X-1,49-52$ & 48.99 & & and B. bramlettei \\
\hline $7 X-2,10-15$ & 50.10 & $<6.6$ & Occurrences of $P$, fistula and $L$. heteroporos \\
\hline $7 X-2,41-43$, to & 50.43 & \multirow{2}{*}{$2.9 / 2.8$} & Occurrence of $L$. neoheteroporos: absence of $C$. davisiana; \\
\hline $8 X-3,24-26$ & 61.27 & & S.peregrina present \\
\hline $8 X-4,104-106$, to & 63.49 & \multirow{2}{*}{$7.5 / 6.4$} & \multirow{2}{*}{ Occurrences of S. peregrina, D. splendens, and $T$. redondoensis } \\
\hline $8 \mathrm{X}-\mathrm{CC}$ & 64.70 & & \\
\hline $9 \mathrm{X}-1,42-45$, to & 67.92 & \multirow{2}{*}{$2.9 / 2.8$} & \multirow{2}{*}{$\begin{array}{l}\text { Occurrence of common } L \text { neoheteroporos: } \\
\text { absence of } C \text {. davisiana }\end{array}$} \\
\hline $11 X-1,44-46$ & 78.44 & & \\
\hline $11 X-3,16-19$, to & 80.61 & \multirow[t]{2}{*}{ ? } & Occurrences of $L$. heteroporos and S. peregrina: \\
\hline $11 \mathrm{X} \cdot \mathrm{CC}$ & 81.30 & & absence of $L$. neoheteroporos \\
\hline $12 X-1,15-18$, to & 87.65 & \multirow[t]{2}{*}{ Barren } & \\
\hline $892 \mathrm{~A}-13 \mathrm{X}-2,36-38$ & 97.65 & & \\
\hline $13 \mathrm{X}-4.55-57$ & 99.33 & $?$ & Occurrence of $L$. heteroporos \\
\hline $13 X-7,138-140$, to & 103.33 & \multirow[t]{2}{*}{ Barren } & \\
\hline $13 X-8,91-93$ & 104.36 & & \\
\hline $13 \mathrm{X}-\mathrm{CC}$ & 106.10 & $?$ & Occurrence of S. peregrina \\
\hline $14 \mathrm{X}-\mathrm{CC}$, to & 107.00 & \multirow[t]{2}{*}{ Barren } & \\
\hline 17X-CC & $\begin{array}{l}136.80 \\
146.90\end{array}$ & & Occurrences of $H$. miocenica and $B$. bramlettei \\
\hline $\begin{array}{l}18 \mathrm{X}, \mathrm{CC} \\
20 \mathrm{X}-1,87-92\end{array}$ & $\begin{array}{l}146.90 \\
164.40\end{array}$ & $<2.9$ & Occurrence of $C$. davisiana \\
\hline $20 X-1,87-92$ & 164.40 & \multirow{3}{*}{ Barren } & \\
\hline $89 \mathrm{~A}-20 \mathrm{X}-1,142-144$, to & 164.92 & & \\
\hline $21 \mathrm{X}-\mathrm{CC}$ & 173.10 & & \\
\hline
\end{tabular}

E. matuyamai, place this interval in the base of the $S$. universus Zone between 0.9 and $1.0 \mathrm{Ma}$.

The interval between Sample 146-892A-1X-2, 126-129 cm, and Sample 146-892A-1X-CC (2.77 to $4.30 \mathrm{mbsf})$, contains representatives of $E$. matuyamai and $L$. neoheteroporos, but no forms such as $L$. nigriniae or $L$. heteroporos. Its age is 1.7 to $1.0 \mathrm{Ma}$ between the LO of $L$. heteroporos and the LO of E. matuyamai. Radiolarian species indicative of upwelling environments, such as $P$. auritum, $P$. grandiporus, P. crustula, and Phormostichoartus schneideri (Nigrini and Caulet, 1992), were found in many samples from this interval.

The FO of E. matuyamai in Sample 146-892A-2X-CC (13.50 mbsf) assigns an age of 1.7 to $2 \mathrm{Ma}$ to the upper interval between 13.02 and 13.50 mbsf.

Below this depth, the occurrence of $C$. davisiana, $L$. neoheteroporos, and $L$. heteroporos in Samples 146-892A-3-1, 14-16 cm, to $-3 \mathrm{X}$-CC (19.14 to $23.20 \mathrm{mbsf}$ ), places this interval in the upper $L$. heteroporos Zone (2.9 to $2 \mathrm{Ma}$ ). Radiolarian species, common in advected waters, testify to a continuous activity of the local upwelling systems.
Immediately below, at 29.14 mbsf (Sample 146-892A-4X-1, 64 $66 \mathrm{~cm}$ ), the composition of the radiolarian assemblage is quite different, with the occurrence of late Neogene forms such as Cycladophora pliocenica and $S$. peregrina and the absence of all other species characteristic of Arctic Pleistocene assemblages. The interval (29.14 to $41.3 \mathrm{mbsf}$ ) between this sample and Sample 146-892A-6X-2, 93-95 $\mathrm{cm}$ (41.43 mbsf), can be dated at 7.5 (FO of $S$. peregrina) to $6.4 \mathrm{Ma}$ (LO of S. peregrina) because late Miocene forms such as Botryopera deflandrei, Theocorys redondoensis, and Prunopyle titan co-occur with $S$. peregrina. No typical representatives of $S$. delmontensis were found. Some close morphotypes reported as ?Stichocorys wolffii may be taken as local forms of $S$. peregrina, considering the great variability of this species in upwelling environments (see taxonomic remarks in the species list).

A hiatus spanning nearly $3 \mathrm{~m} . y$., located between 23.20 and 29.14 mbsf, is inferred from these data.

The radiolarian assemblage observed in Samples 146-892A-6XCC (45.70 mbsf) and 146-892A-7X-1, 49-52 cm (48.99 mbsf), is older because of common middle Miocene forms such as Cyrto- 
capsella japonica. The co-occurrence of these species with representatives of Dictyophimus splendens and T. redondoensis, and the absence of typical specimens of $S$. peregrina, suggest an age of 15.3 to $10 \mathrm{Ma}$ for this interval.

A second hiatus spanning at least 2 to $3 \mathrm{~m} . \mathrm{y}$. is located between 41.43 and $45.70 \mathrm{mbsf}$, above the middle Miocene sequence.

Rare and moderately preserved debris of $L$. heteroporos in Sample 146-892A-7X-2, 10-15 cm at $50.10 \mathrm{mbsf}$, assigns an age younger than $6.6 \mathrm{Ma}$ to this level, suggesting a stratigraphic reversal above this sample.

The stratigraphic reversal below the middle to upper Miocene interval is confirmed by the occurrence of abundant, well-preserved representatives of $L$. neoheteroporos in the interval between Sample 146-892A-7X-2, 41-43 cm (50.43 mbsf), and Sample 146-892A-8X$3,24-26 \mathrm{~cm}$ ( $61.27 \mathrm{mbsf})$. The absence of $C$. davisiana and $S$. peregrina gives an age of 2.8-2.9 Ma to this sequence. Many Arctic forms of late Pliocene to Pleistocene age and upwelling indicators are common. Assemblages are generally well-preserved, and species diversity is high. Rare reworked forms of late Miocene age can be observed.

Two meters down, an older assemblage can be observed in Sample 146-892A-8X-4, 104-106 cm (63.49 mbsf). The occurrence of $S$. peregrina, $D$. splendens, and $T$. redondoensis gives an age of 7.5 to 6.4 Ma to the interval between 63.49 and $64.70 \mathrm{mbsf}$ (Sample 146$892 \mathrm{~A}-8 \mathrm{X}-\mathrm{CC}$ ), suggesting a hiatus of probably $3 \mathrm{~m} . \mathrm{y}$. located between 61.27 and 63.49 mbsf.

Further below this upper Miocene sequence, a second reversal is inferred, as assemblages identical in composition to those observed between 50.43 and 61.27 mbsf are reported for the interval between Samples 146-892A-9X-1, 42-45 cm (67.92 mbsf) and -11X-1, 44-46 $\mathrm{cm}$ (78.44 mbsf). Common abundance of $L$. neoheteroporos and $S$. acquilonium, and the absence of $C$. davisiana, also suggest an age of 2.9-2.8 Ma for this interval. The reversal is located between 64.70 and 67.92 mbsf.

Downhole, radiolarians are very rare and poorly preserved when present. In the interval between Samples 146-892A-11X-3, 16-19 $\mathrm{cm}(80.61 \mathrm{mbsf})$ and $-18 \mathrm{X}-\mathrm{CC}(146.90 \mathrm{mbsf})$, rare representatives of L. heteroporos, Stauroxiphos communis, and $S$. peregrina suggest a late Miocene to early Pliocene age, but preservation is so poor and abundance so rare that no age assignment can be realistically attempted.

Sample 146-892A-20X-1, 87-92 cm, at $164.4 \mathrm{mbsf}$, contains rare and poorly preserved radiolarians. But the occurrence of many easily recognizable representatives of $C$. davisiana suggests a late Pliocene to Pleistocene age $(<2.9 \mathrm{Ma})$ for this sample. Co-occurrence of many representatives of the foraminifer Neogloboquadrina asanoi in Samples 146-892A-20X-1, 87-92 cm, and 146-892A-20X-CC assigns a late Pliocene age (1.9 to $2.8 \mathrm{Ma}$ ) to the interval between 164.4 and $167.4 \mathrm{mbsf}$.

A possible stratigraphic reversal is thus inferred between 146.90 and $164.4 \mathrm{mbsf}$. Although the depth of this inversion cannot be located precisely because the interval lacks well-preserved fauna, its occurrence within this interval is consistent with the position of the major fault zone inferred at this site. Rare recrystallized $r$ idiolarians not identifiable as to the species level were found in most : nples below 87.65 mbsf.

\section{Hole $892 D$}

The co-occurrence of rare but well-preserved representatives of $L$. neoheteroporos and L. nigriniae in Samples 146-892D-1X-CC (8.50 mbsf) to $-2 \mathrm{X}-2,6-8 \mathrm{~cm}$ (10.06 mbsf) assigns an age of $1.2-0.9 \mathrm{Ma}$ to the uppermost part of Hole 892D. Radiolarian assemblages of Arctic and upwelling forms are common to abundant in this interval.

The occurrence of rare specimens of E. matuyamai in Samples 146-892D-2X-CC (18.00 mbsf) and -3X-1, 5-7 cm (18.05 mbsf) gives an age of 2-1 Ma to the interval between 18.00 and $27.50 \mathrm{mbsf}$ (Sample 146-892D-3X-CC). This last sample is tentatively included in the interval, although no representative of E. matuyamai was found in it, because no other changes occur in the radiolarian fauna.

The lower interval between Samples 146-892D-4X-1, 29-31 cm, to $-5 \mathrm{X}-1,52-54 \mathrm{~cm}$ ( 27.79 to $37.52 \mathrm{mbsf})$ is dated 2.9 to $2 \mathrm{Ma}$ because no specimens of $E$. matuyamai were found in assemblages composed of forms such as $L$. neoheteroporos, $C$. davisiana (old forms), C. pliocenica, and E. calvertense.

Two meters below this sequence, a completely different assemblage of middle Miocene age was found in Sample 146-892D-5X-2, 95-97 cm (39.45 mbsf). Species such as C. japonica, D. splendens, $B$. deflandrei, P. titan, L. n. nipponica, and T. redondoensis are present in this sample and in the sediments down to Sample 146$892 \mathrm{D}-7 \mathrm{X}-5,32-34 \mathrm{~cm}$ (60.08 mbsf). An age of 15.5 to $10 \mathrm{Ma}$ is proposed for this interval, suggesting a major hiatus of nearly $7 \mathrm{~m}$.y. between 37.52 and 39.45 mbsf.

The occurrence of common well-preserved representatives of $L$. neoheteroporos, $L$. heteroporos, and C. pliocenica in Sample 146892D-7X-6, 21-23 cm (61.24 mbsf), dated at 2.9-2.8 Ma, suggests a big stratigraphic reversal between 60.09 and 61.24 mbsf. No representatives of $C$. davisiana are present in this sample, but transitional forms of $L$. heteroporos $L$. neoheteroporos suggest an age close to the FO of both $C$. davisiana and $L$. neoheteroporos. An identical radiolarian assemblage of the same age is present in all samples down to 77.60 mbsf (Sample 146-892D-9X-CC). All samples between 102.70 and $109.70 \mathrm{mbsf}$ are barren of radiolarians.

Occurrence of old forms of C. davisiana, with representatives of $L$. neoheteroporos and $L$. heteroporos give an age slightly younger than 2.9-2.8 Ma to the interval between Samples 146-892D-11X-2, $46-48 \mathrm{~cm}$, and $-11 \mathrm{X}-\mathrm{CC}$ ( 111.46 to $119.00 \mathrm{mbsf}$ ). The scarcity and the poor state of preservation of radiolarians does not permit placement of any hiatus or stratigraphic reversal between this sequence and the upper interval.

From Sample 146-892D-12X-2, 91-93 cm (121.41 mbsf) to 146892D-16X-5, 53-55 cm (163.06 mbsf), radiolarian assemblages and radiolarian stratigraphic markers are rare and poorly preserved.

\section{Hole $892 E$}

Five samples from 0.64 to 39.83 mbsf were studied. Radiolarian species are usually rare so no good stratigraphy can be proposed.

\section{CONCLUSIONS}

Radiolarian assemblages are generally rare and moderately to well-preserved in detritic sediments from the Cascadia Margin.

Detailed occurrence of 65 taxa were estimated in 92 samples at Hole $889 \mathrm{~A}$ on the accretionary wedge off Vancouver Island. Age estimates obtained from the radiolarian events range from $0.4 \mathrm{Ma}$ at $29.50 \mathrm{mbsf}$ to younger than 2.9 Ma at $284.10 \mathrm{mbsf}$ (Fig. 2). An average sedimentation rate of $9 \mathrm{~cm} / \mathrm{k} . \mathrm{y}$. can be estimated for the early Pleistocene. No hiatuses are recorded.

$\mathrm{LO}$ and FO of stratigraphic markers were recognized in 50 samples from Hole 892A, and in 47 samples from Hole 892D, on the accretionary wedge of the Oregon continental slope. An intricate stratigraphy for Hole 892A is proposed (Fig. 3), from the top to the bottom:

1. approximately $1.5 \mathrm{~m}$ of Pleistocene sediments (1-0.9 Ma);

2. a small interval $(1.6 \mathrm{~m})$ of lower Pleistocene material (1.7-1 Ma);

3. a hiatus of about 3 m.y., located between 23.2 and $29.1 \mathrm{mbsf}$;

4. a short sequence (12 m) of late Miocene age (7.5-6.4 Ma); 
5. second hiatus spanning 2 to 3 m.y., located between 41.43 and 45.70 mbsf;

6. the first stratigraphic reversal between 49 and $50.50 \mathrm{mbsf}$;

7. an upper Pliocene sequence (2.9-2.8 Ma) from 50.43 to 61.27 mbsf;

8. a third hiatus of approximately 3 m.y., located between 61.27 and $63.49 \mathrm{mbsf}$;

9. a very short interval ( $1.3 \mathrm{~m}$ thick) of late Miocene age ( 7.5 to $6.4 \mathrm{Ma}$ );

10. a second stratigraphic reversal located between 65 and 67 mbsf;

11. a Pliocene interval between 67.92 and 78.44 mbsf, identical in age (2.9-2.8 Ma) and fauna to the upper Pliocene interval above the third hiatus;

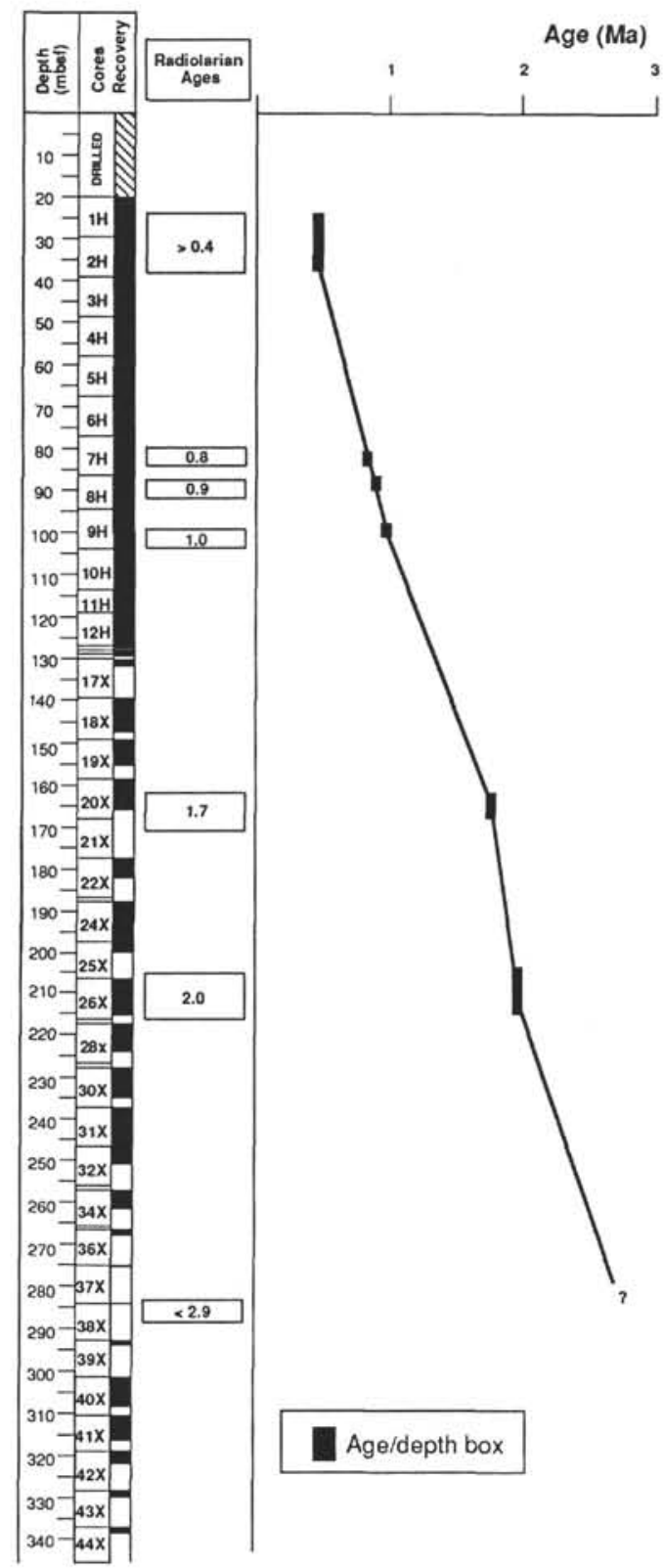

Figure 2. Age-depth plot for Hole 889A.
12. a thick sequence of sediments with no characteristic radiolarians and unknown age from 80.61 to $146.9 \mathrm{mbsf}$;

13. a possible third stratigraphic reversal between 146 and $164.54 \mathrm{mbsf}$;

14. a sample younger than $2.9 \mathrm{Ma}$ at $164.4 \mathrm{mbsf}$;

15. a downhole sequence barren of radiolarians.

Occurrence of many radiolarian species characteristic of upwelling environment suggests that upwelling activity occurred along the Oregon margin during most of the late Pliocene to early Pleistocene.

\section{SPECIES LIST}

This list includes bibliographic references for all the taxa that were counted in this study, and some additional remarks about new taxonomic combinations, or morphological peculiarities. The only literature references given are to the original description and to my present concept of the species if different from the original one.

Some groups (mostly actinommids, trissocyclids, and botryoids) were purposely not included in this study because taxonomic concepts of these groups are not yet clear.

Some apparently new morphotypes were not described because their occurrences were scarce and no stratigraphic range could be determined for them.

Acrosphaera murrayana (Haeckel). Choenicosphaera murrayana Haeckel, 1887, p. 102, pl, 8, fig. 4. Acrosphaera murrayana (Haeckel) in Hilmers, 1906, p. 63.

Actinomma leptodermum (Jørgensen), n. comb. Echinomma leptodermum Jørgensen, 1905, p. 116, pl. 8, fig. 33. Included in the genus Actinomma without a specific validation by M.G.Petrushevskaya, in Petrushevskaya and Kozlova, 1979, p. 98.

Actinomma popofskii (Petrushevskaya). Echinomma popofskii Petrushevskaya, 1967, p. 23, fig. 12, I-III. Actinomma popofskii (Petrushevskaya) in Caulet, 1986, p. 851.

Anthocyrtidium pliocenica (Seguenza). Anthocyrtis ehrenbergi Stöhr var. pliocenica Seguenza, 1880, p. 232. Anthocyrtidium pliocenica (Seguenza) in Nigrini and Caulet, 1988, p. 355, pl. 2, figs. 5-6.

Botryopera deflandrei Petrushevskaya, 1975, p. 592, pl. I l, figs. 30-32.

Botryostrobus aquilonaris (Bailey). Eucyrtidium aquilonaris Bailey, 1856, p. 4, pl. 1, fig. 9. Botryostrobus aquilonaris (Bailey) in Nigrini, 1977, p. 246, pl. 1, fig. 1 .

Botryostrobus aquilonaris aff. This morphotype differs from the $B$. acquilonaris type by its larger size and additional post-thoracic segments. Stratigraphic range unknown.

Botryostrobus bramlettei bramlettei (Campbell and Clark). Lithomitra bramlettei Campbell and Clark, 1944, p. 53, pl. 7, figs. 10-14. Botryostrobus b. bramlettei (Campbell and Clark) in Caulet, 1979, p. 129, pl. 1, fig. 8.

Botryostrobus bramlettei costatus (Stöhr). n. comb. Dictyomitra costata Stöhr, 1880 , p. 101, pl. 3, fig. 23. This form has been recently rediscovered in the Messinian of Sicily (Caulet, in prep.).

Botryostrobus bramlettei pretumidulus Caulet, 1979, p. 129, pl. 1, fig. 5.

Botryostrobus bramlettei seriatus (Jørgensen) Eucyrtidium seriatum Jørgensen, 1905, p. 150. Botryostrobus bramlettei seriatus (Jørgensen) in Caulet, 1979, p. 130, pl. 1, fig. 6, text-fig. 4.

Botryostrobus bramlettei tumidulus (Bailey). Eucyrtidium tumidulus Bailey, 1856, p. 5, pl. 1, fig. Il. Botryostrobus bramlettei tumidulus (Bailey) in Caulet, 1979, p. 131, pl. 1, fig. 9.

Ceratocyrtis histricosa (Jørgensen). Helotholus histricosa Jørgensen, 1905, p. 137, pl. 16, figs. 86-88. Ceratocyrtis histricosa (Jørgensen) in Petrushevskaya, 1971 b, p. 98 , fig. $52,2-4$.

Ceratospyris borealis Bailey, 1856, p. 31, pl. 1, fig. 3; Nigrini and Moore, 1979, N, Pl. 19, figs. la-d.

Cycladophora bicornis amphora Lombari and Lazarus, 1988, p. 110, pl. 4, figs. 6-12. Under this name are grouped those Cycladophora having a thorax clearly divided into an elongated upper thorax, and an elongated to equant, narrowly flared, and flat in outline, lower thorax. One of the two forms described by Bailey (1856, fig. 13) under the name of Halicalyptra? 


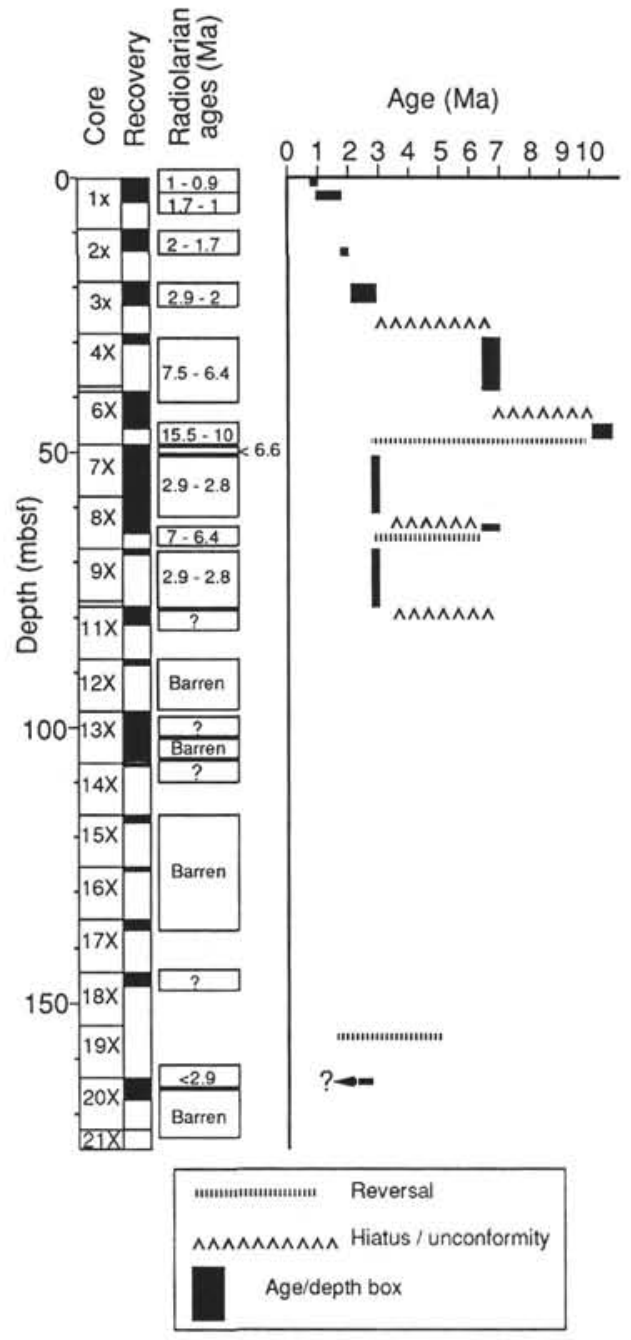

Figure 3. Age-depth plot for Hole 892A.

cornuta (1856, p. 5, pl. 1) looks very similar to the morphotypes counted under this name, but Bailey's name has mostly been used to described those Cycladophora having a cylindrical thorax not divided in two parts, similar to the second form described by Bailey (1856, fig. 15).

Cycladophora bicornis helios Lombari and Lazarus, 1988, p. 114, pl. 5, figs. 1-8.

Cycladophora davisiana davisiana (Ehrenberg). Cycladophora? davisiana, Ehrenberg, 1861, p. 297; 1873, pl. 2, fig.11. Cycladophora davisiana davisiana Ehrenberg in Petrushevskaya, 1967, p. 122, fig. 69 (I-VII). Early representatives of $C$. davisiana are more robust and shorter than their common descendants. They are referred here as " $C$. davisiana old".

Cycladophora pliocenica (Hays). Clathrocyclas bicornis Hays, 1965, p. 179, pl. 3, fig. 3. Cycladophora pliocenica (Hays) Lombari and Lazarus, 1988, p. 104.

Cycladophora robusta Lombari and Lazarus, 1988, p. 105, pl. 2, figs. 1-14.

Cyrtocapsella japonica (Nakaseko). Eusyringium japonicum Nakaseko, 1963, p. 193, pl. 4, figs. 1-3. Cyrtocapsella japonica (Nakaseko) in Sanfilippo and Riedel, 1970, p. 452, pl. 1, figs. 13-15.

Dictyophimus crisiae Ehrenberg, 1854, p. 241. Nigrini, 1967, p. 66, pl. 6, figs. $7 \mathrm{a}, \mathrm{b}$.

Dictyophimus splendens (Campbell and Clark). Pterocorys (Pterocyrtidium) splendens Campbell and Clark, 1944, p. 46, pl. 6, figs. 19, 20. Dictyophimus splendens (Campbell and Clark) in Caulet, 1986, p. 852. Emend. Morley and Nigrini, in press.

Eucyrtidium calvertense Martin, 1904, p. 450, pl. 130, fig. 5.

Eucyrtidium matuyamai Hays, 1970, p. 213, pl. 1, figs. 7, 9.

Eucyrtidium teuscheri teuscheri Caulet, 1986, p. 851, pl. 5, figs. 5-8.
Gondwanaria dogieli (Petrushevskaya). Sethoconus? dogieli Petrushevskaya, 1967, p. 95, pl. 53, figs. 1, 2. Gondwanaria dogieli (Petrushevskaya), in Petrushevskaya, 1975, p. 585.

Haliommetta miocenica (Campbell and Clark). Heliosphaera miocenica Campbell and Clark, 1944a, p. 16, pl. 2, figs. 10-14. Haliommetta miocenica (Campbell and Clark), in Petrushevskaya and Kozlova, 1972, p. 517. pl. 9 , figs. 8,9 .

Lamprocyclas hannai (Campbell and Clark). Calocyclas hannai Campbell and Clark, 1944a, p. 48, pl. 69, figs. 21, 22. Lamprocyclas hannai (Campbell and Clark) in Caulet 1986, p. 852.

Lamprocyclas junonis (Haeckel). Theoconus junonis Haeckel, 1887, p. 1401 , pl. 69, fig. 7. Lamprocyclas junonis (Haeckel) in Caulet, 1986, p. 852, pl. 4 , fig. 10.

Lamprocyclas margatensis (Campbell and Clark). Calocyclas margatensis Campbell and Clark, 1944a, p.47, pl. 6, figs, 17-18. Lamprocyclas margatensis (Campbell and Clark) in Caulet, 1986, p. 852, pl. 4, fig. 3.

Lamprocyrtis heteroporos (Hays). Lamprocyclas heteroporos Hays, 1965, p. 179, pl. 3, fig. 1. Lamprocyrtis heteroporos (Hays), in Kling, 1973, p. 639, pl. 5, figs. 19-21, pl. 15, fig. 6.

Lamprocyrtis neoheteroporos Kling. Lamprocyrtis neoheteroporos Kling, 1973, p. 639 , pl. 5 , figs. 17,18 , pl. 15 , figs. 4,5 .

Lamprocyrtis nigriniae (Caulet). Conarachnium nigriniae Caulet, 1971 p. 3 pl. 3, figs. 1-4, pl. 4, figs. 1-4. Lamprocyrtis nigriniae (Caulet) in Kling, 1977, p. 217, pl. 1, fig. 17.

Lipmanella acanthica (Jørgensen). n. comb. Dictyoceras acanthicum Jørgensen, 1905, p. 140, pl. 17, fig. 101a, pl. 18, fig. 101b. Included in the genus Lipmanella without a specific validation by M.G. Petrushevskaya, in Petrushevskaya and Kozlova, 1979, p. 137.

Lychnocanoma nipponica nipponica (Nakaseko). Lychnocanium nipponicum Nakaseko, 1963, p. 168, text-fig. 2, pl. 1, figs. 10-14. Lychnocanoma nipponica nipponica (Nakaseko) in Morley and Nigrini, in press.

Lychnocanoma nipponica sakai Morley and Nigrini, in press, pl. 7, figs. 1, 3 .

Phormostichoartus caryoforma (Caulet). Lithamphora caryoforma Caulet, 1979, p. 131, pl. 2, fig. 2. Phormostichoartus caryoforma (Caulet) in $\mathrm{Ni}-$ grini and Caulet, 1992, p. 161, pl. 6, figs. 7, 9.

Phormostichoartus crustula (Caulet). Lithamphora crustula Caulet, 1979, p. 131, pl. 2, fig. 1. Phormostichoartus crustula (Caulet) in Nigrini and Caulet, 1992, p. 161, pl. 6, figs. 10-14.

Phormostichoartus fistula Nigrini, 1977, p. 253, pl. 1, figs. 11-13,

Phormostichoartus multiseriatus (Ehrenberg). Eucyrticium multiseriatum Ehrenberg, 1860, p. 768. Lithocampe? multiseriata (Ehrenberg) in Petrushevskaya, 1967, p. 135, fig. 16,1-111. Phormostichoartus multiseriatus (Ehrenberg) in Caulet, 1986, p. 853.

Phormostichoartus pitomorphus Caulet, 1986a, p. 850, pl. 3, figs. 3, 4, 9, 10, 12.

Phormostichoartus schneideri Nigrini and Caulet, 1992, p. 160, pl. 6, figs. 3 6.

Prunopyle titan gr. Campbell and Clark, 1944a, p. 20, pl. 3, figs. 1-3. Arctic Pacific forms are rare and smaller than Antarctic forms.

Pseudocubus vema (Hays). Helotholus vema Hays, 1965, p. 176, pl. 2, fig. 3, text fig. A. Pseudocubus vema (Hays) in Petrushevskaya, 1971a, p. 46, fig. 24, I-IV. Arctic forms are smaller than Antarctic ones. They are so scarce that a serious morphological study cannot be undertaken.

Pseudodictyophimus gracilipes (Bailey) gr. Dictyophimus gracilipes Bailey, 1856, p. 4, pl. I, fig. 8. Pseudodictyophimus gracilipes (Bailey) in Petrushevskaya, 1971b, p. 93, figs. 47-49.

Pterocanium auritum Nigrini and Caulet, 1992, p. 152, pl. 4, figs. 6-8.

Pterocanium grandiporus Nigrini, 1968, p. 57, pl. 1, fig. 7.

Pterocanium korotnevi (Dogel). Pterocorys korotnevi Dogel in Dogel and Reshetnyak, 1952, p. 17, fig. 11. Pterocanium korotnevi (Dogel) in Nigrini, 1970 , p. 170 , pl. 3 , figs. 10,11 .

Pterocanium trilobum (Haeckel). Dictyopodium trilobum Haeckel, 1860, p. $839 ; 1862$, p. 340 , pl. 8, figs. 6-10. Pterocanium trilobum (Haeckel) in Haeckel, 1887, p. 1333.

Pterocorys clausus (Popofsky). Lithornithium clausum Popofsky, 1913, p. 393, text fig. I l. Pterocorys clausus (Popofsky) in Petrushevskaya and Kozlova, 1972, p. 545, pl. 36, figs. 16-18.

Rhizosphaera antarctica (Haeckel). Spongoplegma antarctica Haeckel, 1887. p. 90. Rhizosphaera antarcticum (Haeckel) in Caulet, 1986a, p. 853.

Siphocampe arachnea (Ehrenberg) group. Eucyrtidium lineatum arachneum Ehrenberg, 1861, p. 299. Lithomitra arachnea (Ehrenberg) in Riedel, 1958, p. 242, pl. 4, figs. 7, 8. Siphocampe arachnea (Ehrenberg) gr. in Nigrini, 1977 , p. 255 , pl. 3 , figs. 7,8 . 
Siphocampe modeloensis (Campbell and Clark). Lithocampe modeloensis Campbell and Clark, 1944a, p. 59 pl. 7, figs. 28-30. Siphocampe modeloensis (Campbell and Clark) in Caulet, 1986, p. 853.

Sphaeropyle langii Dreyer, 1889, p. 13, pl. 4, fig. 54. Emend Foreman, 1975 , p. 618, pl. 9, figs. 30-31. Emend Morley and Nigrini, in press.

Sphaeropyle robusta Kling, 1973, p. 634, pl. 1, figs. 11-12, pl. 6, figs. 9-13, pl. 13, figs. 1-5. Emend Foreman, 1975, p. 618, pl. 9, figs 24-26. Emend Morley and Nigrini, in press.

Spirema sp. Spirema sp. in Kling, 1973, p. 635, pl. 7, figs. 23-25.

Spongodiscus osculosus (Dreyer). Spongopyle osculosa Dreyer, 1889, p. 42, figs. 99, 100. Spongodiscus osculosus (Dreyer) in Petrushevskaya, 1967. p. 42 , figs. $20-22$.

Spongotrochus glacialis Popofsky, 1908, p. 228, pl. 27, fig. 1, pl. 28, fig. 2.

Spongotrochus? venustum (Bailey). Perichlamydium venustum Bailey, 1856 , p. 5, pl. I, figs. 16, 17. Spongotrochus? venustum (Bailey) in Nigrini and Moore,1979, S119, pl. 15, figs. 3a, b.

Stauroxiphos communis Carnevale, 1908, p. 15, pl. 2, fig. 9.

Stichocorys peregrina (Riedel). Eucyrtidium elongatum peregrinum Riedel, 1953 , p. 812 , pl. 85 , fig. 2. Stichocorys peregrina (Riedel) in Sanfilippo and Riedel, 1970, p. 451, pl. 1, fig. 10.

?Stichocorys wolffii Haeckel, 1887, p. 1479, pl. 80, fig. 10. Arctic forms seem to be more spinose than tropical ones. Relationships between tropical and high latitude forms are not entirely understood. There is still an uncertainty about the taxonomic determination of these forms because their last occurrence seems to be much younger ( 7 to $6.4 \mathrm{Ma}$ ) in Leg 146 material than in tropical material (LO dated around $11.6 \mathrm{Ma}$ in Leg 85 material, see Nigrini, 1985).

Stylacontarium acquilonium (Hays). Druppatractus acquilonius Hays, 1970. p. 214, pl. 1, figs 4-5. Stylacontarium acquilonium (Hays) in Kling, 1973, p. 634 , pl. 1 , figs. $17-20$, pl. 14, figs. $1-4$.

Stylacontarium sp. aff. S. bispiculum Kling, 1973, p. 634, pl. 6, fig. 6. 19-23, pl. 14, figs. $5-8$. These forms are too rare in Leg 146 material to attempt a comparison with Antarctic forms.

Stylatractus universus Hays, 1965, p. 167, pl. 1, fig. 6.

Theocorys redondoensis (Campbell and Clark). Theocyrtis redondoensis Campbell and Clark, 1944a, p. 49, pl. 7, fig. 4. Theocorys redondoensis (Campbell and Clark) in Kling, 1973, p. 638, pl. 11, figs. 26-28.

Theocorythium trachelium trachelium (Ehrenberg). Eucyrtidium trachelium Ehrenberg, 1872a, p. 312. Theocorythium trachelium trachelium (Ehrenberg) in Nigrini, 1967, p. 79, pl. 8, fig. 2, pl. 9, fig. 2. Early representatives of an older form similar to $T$. trachelium are referred here under the name of " $T$. trachelium old". The description and a picture of this form (pl. 1, fig. 3) are given in a paper from Caulet et al. (1993).

Tricolocapsa papillosa (Ehrenberg) gr. Eucyrtidium papillosum Ehrenberg, 1872a, p. $310 ; 1872$ b, pl. 7, fig. 10. Tricolocapsa papillosa (Ehrenberg) gr. in Petrushevskaya and Kozlova, 1972, p. 537, pl. 22, fig. 31.

\section{ACKNOWLEDGMENTS}

Financial support for the cruise and this study was provided by INSU grant "Soutien à ODP-France" No. 9339 10. The author is much indebted to Joe Morley for communication of his new "radiolarian ages" for the North Pacific (Leg 145), and to David Lazarus for taxonomic discussions about Arctic forms and biostratigraphy. Thanks are due to C. Nigrini and A. Sanfilippo for the critical review of the manuscript. M. Tamby competently assisted with the preparation of samples.

\section{REFERENCES}

Bailey, J.W., 1856. Notice of microscopic forms found in the soundings of the Sea of Kamtschatka-with a plate. Am. J. Sci. Arts, Ser. 2, 22:1-6.

Campbell, A.S., and Clark, B.L., 1944. Miocene radiolarian faunas from Southern California. Spec. Pap.-Geol. Soc. Am., 51:1-76.

Carnevale, P., 1908. Radiolarie e silicoflagellati di Bergonzano (Reggio Emilia). Veneto Sci. Lett. Arti Mem., 28:1-46.

Caulet, J.-P., 1971. Contribution à l'étude de quelques Radiolaries Nassellaires des boues de la Méditerranée et du Pacifique (Study of some nassellarian Radiolaria from Mediterranean and Pacific sediments). Archives originale, Centre de Documentation, C.N.R.S., No. 498. Cah Micropaleontol., Ser. 2, 10:1-10.
1979. Les dépôts à radiolaires d'âge Pliocène supérieur à Pléistocene dans l'océan Indiencentral: nouvelle zonation biostratigraphique (Radiolarian upper Pliocene-Pleistocene deposits in the central Indian Ocean: new biostratigraphic zonation). Mem. Mus. Nat. Hist. Nat. Ser. C, 43:119-141.

- 1986. Radiolarians from the southwest Pacific. In Kennett, J.P., von der Borch, C.C., et al., Init. Repts. DSDP, 90: Washington (U.S. Govt. Printing Office), 835-861.

1991. Radiolarians from the Kerguelen Plateau, Leg 119. In Barron, J., Larsen, B., et al., Proc. ODP, Sci. Results, 119: College Station, TX (Ocean Drilling Program), 513-546.

Caulet, J.-P., Nigrini, C., and Schneider, D.A., 1993. High resolution Pliocene-Pleistocene radiolarian stratigraphy of the tropical Indian Ocean. Mar. Micropaleontol., 22:111-129.

De Wever, P., Caulet, J.-P., and Bourgois, J., 1990. Radiolarian biostratigraphy from Leg 112 on the Peru margin. In Suess, E., von Huene, R., et al., Proc. ODP, Sci. Results, 112: College Station, TX (Ocean Drilling Program), 181-207.

Dogel, V.A., and Reshetnyak, V.V., 1952. Materialy po radiolyaryam severozapadnoi chasti tikhogo okeana (Material on radiolarians of the northwestern part of the Pacific Ocean). Issled. Dal'nevost. Morei SSSR, 3:5-36.

Dreyer, F., 1889. Morphologische Radiolarienstudien. 1. Die Pylombildungen in vergleichend-anatomischer und entwicklungsgeschichtlicher Beziehung bei Radiolarien und bei Protisten überhaupt, nebst System und Beschreibung neuer und der bis jetzt bekannten pylomatischen Spumellarien. Jena. Z. Naturwiss., 23:1-138.

Ehrenberg, C.G., 1854. Über das Organischen Leben des Meeresgrundes in bis 10,800 und 12,000 Fuss Tiefe. K. Preuss. Akad. Wiss. Berlin, Bericht, 1854:54-75.

, 1860. Über den Tiefgründ des stillen Oceans zwischen Californien und den Sandwich-Inseln aus bis 15600' Tiefe nach Lieutenant Brooke. K. Preuss. Akad. Wiss. Berlin, Monatsberichte, 1860:819-833.

, 1861. Über den Tiefgrund-Verhaltnisse des Oceans am Eingange der Davisstrasse und bei Island. K. Preuss. Akad. Wiss. Berlin, Monatsberichte, 1861:275-315.

, 1872a. Mikrogeologische Studien als Zusammenfassung der Beobachtungen des kleinsten Lebens der Meeres-Tiefgrunde aller Zonen und dessen geologischen Einfluss. K. Preuss. Akad. Wiss. Berlin, Monatsberichte, 265-322.

1872b. Mikrogeologische Studien über das kleinste Leben der Meeres-Tiefgrunde aller Zonen und dessen geologischen Einfluss. Abh. K. Akad. Wiss, Berlin, 131-399.

1873. Grössere Felsproben des Polycystinen-Mergels von Barbados mit weiteren Erläuterungen. K. Preuss. Akad. Wiss. Berlin, Monatsberichte, Jahre 1873:213-263.

Foreman, H.P., 1975. Radiolaria from the North Pacific, Deep Sea Drilling Project, Leg 32. In Larson, R.L.. Moberly, R., et al., Init. Repts. DSDP. 32: Washington (U.S. Govt. Printing Office), 579-676.

Haeckel, E., 1860. Fernere Abbildungen und Diagnosen neuer Gattungen und Arten von lebenden Radiolarien des Mittelmeeres (Supplementary illustrations and diagnosis of new genera and species of living radiolarians of the Mediterranean Sea). K. Preuss. Akad. Wiss. Berlin, Monatsberichte, 835-845.

1862. Die Radiolarien (Rhizopoda Radiolaria): Berlin (Reimer).

1887. Report on the Radiolaria collected by H.M.S. Challenger during the years 1873-1876. Rep. Sci. Results Voy. H.M.S. Challenger, 1873-1876, Zool., 18:1-1803.

Hays, J.D., 1965. Radiolaria and late Tertiary and Quaternary history of Antarctic seas. In Llano, G.A. (Ed.), Biology of the Antarctic Seas II. Antarct. Res. Ser., 5:125-184.

1970. Stratigraphy and evolutionary trends of radiolaria in North Pacific deep sea sediments. In Hays, J.D. (Ed.), Geological Investigations of the North Pacific. Mem.-Geol. Soc. Am., 126:185-218.

Hilmers, C., 1906. Zur Kenntnis der Collosphaeriden: Kiel (Druck von C. Schaidt).

Jørgensen, E., 1905. The protist plankton and the diatoms in bottom samples. Bergens Mus. Skr., 49-151, 195-225.

Kling, S.A., 1971. Radiolaria: Leg 6 of the Deep Sea Drilling Project. In Fischer, A.G., Heezen, B.C., et al., Init. Repts. DSDP, 6: Washington (U.S. Govt. Printing Office), 1069-1117.

1973. Radiolaria from the eastern North Pacific, Deep Sea Drilling Project, Leg 18. In Kulm, L.D., von Huene, R., et al., Init. Repts. DSDP, 18: Washington (U.S. Govt. Printing Office), 617-671. 
1977. Local and regional imprints on radiolarian assemblages from California coastal basin sediments. Mar. Micropaleontol., 2:207221 .

Lombari, G., and Lazarus, D.B., 1988. Neogene cycladophorid radiolarians from North Atlantic, Antarctic, and North Pacific deep-sea sediments. Micropaleontology, 34:97-135.

Martin, G.C., 1904. Radiolaria. In Clark, W.B., Eastman, C.R., Glenn, L.C., Bagg, R.M., Bassler, R.S., Boyer, C.S., Case, E.C., and Hollick, C.A. (Eds.), Systematic Paleontology of the Miocene Deposits of Maryland: Baltimore (Maryland Geol. Surv., Johns Hopkins Press), 447-459.

Morley, J.J., 1985. Radiolarians from the Northwest Pacific, Deep Sea Drilling Project Leg 86. In Heath, G.R., Burckle, L.H., et al., Init. Repts. DSDP, 86: Washington (U.S. Govt. Printing Office), 399-422.

Morley, J.J., and Nigrini, C., in press. Miocene to Pleistocene radiolarian biostratigraphy of North Pacific Sites 881, 884, 885, 886, and 887. In Rea, D.K., Basov, I.A., Scholl, D.W., and Allan, J.F. (Eds.), Proc. ODP, Sci. Results, 145: College Station, TX (Ocean Drilling Program).

Nakaseko, K., 1963. Neogene Cyrtoidea (Radiolaria) from the Isozaki Formation in Ibaraki Prefecture, Japan. Sci. Rep., Coll. Gen. Educ., Osaka Univ., 12:165-198.

Nigrini, C., 1967. Radiolaria in pelagic sediments from the Indian and Atlantic Oceans. Bull. Scripps Inst. Oceanogr., 11:1-125.

1968. Radiolaria from eastern tropical Pacific sediments. Micropaleontology, 14:51-63.

1970. Radiolarian assemblages in the North Pacific and their application to a study of Quaternary sediments in core V20-130. In Hays, J.D. (Ed.), Geological Investigations of the North Pacific. Mem.-Geol. Soc. Am., 126:139-183.

1977. Tropical Cenozoic Artostrobiidae (Radiolaria). Micropaleontology, 23:241-269.

, 1985. Radiolarian biostratigraphy in the central equatorial Pacific, Deep Sea Drilling Project Leg 85. In Mayer, L., Theyer, F., Thomas, E., et al., Init. Repts. DSDP, 85: Washington (U.S. Govt. Printing

Nigrini, C., and Moore, T.C., 1979. A Guide to Modern Radiolaria. Spec. Publ. Cushman Found. Foraminiferal Res., 16.

Nigrini, C.A., and Caulet, J.P., 1988. The genus Anthocyrtidium (Radiolaria) from the tropical late Neogene of the Indian and Pacific Oceans. Micropaleontology, 34:341-360.

1992. Late Neogene radiolarian assemblages characteristic of Indo-Pacific areas of upwelling. Micropaleontology, 38:139-164.

Petrushevskaya, M.G., 1967. Radiolyarii otryadov Spumellaria i Nassellaria antarkticheskoi oblasti (Antarctic Spumelline and Nasselline radiolarians). In Resultaty Biologicheskikh Issledovanii Sovetskoi Antarktichesko Ekspeditsii 1955-1958 (Vol. 3): Issled. Fauny Morei, Zool. Inst. Akad. Nauk SSSR, 4:1-186.

1971a. On the natural system of polycystine Radiolaria (Class Sarcodina). In Farinacci, A. (Ed.), Proc. 2nd Planktonic Conf. Roma: Rome (Ed. Tecnosci.), 981-992.

, 1971b. Radiolyarii Nassellaria v planktone Mirovogo okeana. In Bykhovshii, B.E. (Ed.), Radiolyarii Mirovogo Okeana po materialam
Sovetskikh ekspeditisii. Issled. Fauny Morei, Leningrad (Nauka), 9:3294.

1975. Cenozoic radiolarians of the Antarctic, Leg 29, DSDP. In Kennett, J.P., Houtz, R.E., et al., Init. Repts. DSDP, 29: Washington (U.S. Govt. Printing Office), 541-675.

Petrushevskaya, M.G., and Kozlova, G.E., 1972. Radiolaria, Leg 14, Deep Sea Drilling Project. In Hayes, D.E., Pimm, A.C., et al., Init. Repts. DSDP, 14: Washington (U.S. Govt. Printing Office), 495-648.

, 1979. Opisanie rodov i vidov radiolyarii (Description of the radiolarian genera and species). Akad. Nauk SSSR, Zool. Inst., Issled. Fauny Morei, 23:86-157.

Popofsky, A., 1908. Die Radiolarien der Antarktis (mit Ausnahme der Tripyleen) (Radiolarians from the Antarctic, Trypylida excepted). In Drygalski, E. (Ed.), Deutsche Süd-Polar Expedition, 1901-1903, 10 (Pt. 3): Berlin (G. Reimer), 183-306.

, 1913. Die Nassellarien des Warmwassergebietes (Nassellaria from warm water areas). In Drygalski, E. (Ed.), Deutsche Süd-Polar Expedition, 1901-1903, 14 (Pt. 2): Berlin (G. Reimer), 217-416.

Riedel, W.R., 1953. Mesozoic and late Tertiary Radiolaria of Rotti. J. Paleontol., 27:805-813.

1958. Radiolaria in Antarctic sediments. Rep. B.A.N.Z Antarct. Res. Exped., Ser. B, 6:217-255.

Riedel, W.R., and Sanfilippo, A., 1970. Radiolaria, Leg 4, Deep Sea Drilling Project. In Bader, R.G., Gerard, R.D., et al., Init. Repts. DSDP. 4: Washington (U.S. Govt. Printing Office), 503-575.

1971. Cenozoic Radiolaria from the western tropical Pacific, Leg 7. In Winterer, E.L., Riedel, W.R., et al., Init. Repts. DSDP, 7 (Pt. 2): Washington (U.S. Govt. Printing Office), 1529-1672.

,- 1978 . Stratigraphy and evolution of tropical Cenozoic radiolarians. Micropaleontology, 24:61-96.

Sanfilippo, A., and Riedel, W.R., 1970. Post-Eocene "closed" theoperid radiolarians. Micropaleontology, 16:446-462.

Sanfilippo, A., Westberg-Smith, M.J., and Riedel, W.R., 1985. Cenozoic Radiolaria. In Bolli, H.M., Saunders, J.B., and Perch-Nielsen, K. (Eds.), Plankton Stratigraphy: Cambridge (Cambridge Univ. Press), 631-712.

Seguenza, G., 1880. Le formazione terziarie nella provincia di Reggio (Calabria). Atti R. Accad. Lincei, 3:1-446.

Stöhr, E., 1880. Die Radiolarienfauna der Tripoli von Grotte, Provinz Girgenti in Sicilien (The radiolarian fauna of the Tripoli of Grotte, Girgenti Province, Sicily). Paleontographica, 26:69-124.

Westbrook, G.K., Carson, B., Musgrave, R.J., et al., 1994. Proc. ODP, Init. Repts., 146 (Pt. 1): College Station, TX (Ocean Drilling Program).

Date of initial receipt: 29 August 1994

Date of acceptance: 3 February 1995

Ms 146SR-205 